\title{
Systems Pharmacology and Microbiome Dissection of Shen Ling Bai Zhu San Reveal Multiscale Treatment Strategy for IBD
}

\author{
Wei-jie Lv $\mathbb{D}$, ${ }^{1}$ Cui Liu $\left(\mathbb{D},{ }^{1}\right.$ Yue-fei Li $\left(\mathbb{D},{ }^{1}\right.$ Wen-qian Chen $\left(\mathbb{D},{ }^{1}\right.$ Zeng-quan Li $\left(\mathbb{D},{ }^{1}\right.$ Yue Li $(\mathbb{D})^{1}$ \\ Ying Xiong $\left(1,{ }^{1}\right.$ Li-min Chao $\left(1,{ }^{1}\right.$ Xiao-long Xu $\left(\mathbb{0},{ }^{2}\right.$ and Shi-ning Guo $\oplus^{1,3}$ \\ ${ }^{1}$ College of Veterinary Medicine, South China Agricultural University, Guangzhou 510642, China \\ ${ }^{2}$ Beijing Hospital of Traditional Chinese Medicine, Affiliated with Capital Medical University, Beijing 100010, China \\ ${ }^{3}$ Guangdong Research Center for Veterinary Traditional Chinese Medicine and Natural Medicine Engineering Technology, \\ Guangzhou 510642, China
}

Correspondence should be addressed to Xiao-long Xu; xiaolong_xu3013@126.com and Shi-ning Guo; shining@scau.edu.cn

Received 22 February 2019; Revised 19 April 2019; Accepted 30 May 2019; Published 23 June 2019

Academic Editor: Ilaria Peluso

Copyright (c) 2019 Wei-jie Lv et al. This is an open access article distributed under the Creative Commons Attribution License, which permits unrestricted use, distribution, and reproduction in any medium, provided the original work is properly cited.

Generally, inflammatory bowel disease (IBD) can be caused by psychology, genes, environment, and gut microbiota. Therefore, IBD therapy should be improved to utilize multiple strategies. Shen Ling Bai Zhu San (SLBZS) adheres to the aim of combating complex diseases from an integrative and holistic perspective, which is effective for IBD therapy. Herein, a systems pharmacology and microbiota approach was developed for these molecular mechanisms exemplified by SLBZS. First, by systematic absorption-distribution-metabolism-excretion (ADME) analysis, potential active compounds and their corresponding direct targets were retrieved. Then, the network relationships among the active compounds, targets, and disease were built to deduce the pharmacological actions of the drug. Finally, an "IBD pathway" consisting of several regulatory modules was proposed to dissect the therapeutic effects of SLBZS. In addition, the effects of SLBZS on gut microbiota were evaluated through analysis of the V3-V4 region and multivariate statistical methods. SLBZS significantly shifted the gut microbiota structure in a rat model. Taken together, we found that SLBZS has multidimensionality in the regulation of IBD-related physiological processes, which provides new sights into herbal medicine for the treatment of IBD.

\section{Introduction}

Recent studies have revealed several factors responsible for the digestive diseases such as irritable bowel syndrome/inflammatory bowel disease (IBS and IBD) [1-5]. However, the cellular mechanisms behind these diseases are complex and unclear. In recent years, much attention has been focused on the development of herbal medicine for the treatment of digestive diseases. Shen Ling Bai Zhu San (SLBZS), which is composed of 10 herbs, has been proven to have wide pharmacological effects on digestive diseases, including antiinflammatory and gut microbiota modulation effect $[6,7]$.

A majority of herbal medicines exert pharmacological effects by targeting multiple host molecules. However, it is difficult to identify these herbal medicine targets. Therefore, a new method that can identify the active compounds and pharmacological targets of herbal medicine is in urgent need of development [8].

Systems pharmacology, which combines oral bioavailability prediction, multitarget prediction, and network analyses, is used to identify the active compounds and pharmacological targets of herbal medicine [9-11]. Herein, we applied the systems pharmacology method to explore the pharmacological mechanisms of SLBZS.

Additionally, high-throughput sequencing has been used to promote our understanding of the role of gut microbiota in health and disease [12]. For example, small intestinal bacterial overgrowth [13] and altered intestinal microbiota [14] are implicated in subgroups of patients with functional bowel disorders. However, due to the inherent limitations of the 
diagnostic methods, the exact evidence of the causal role of microbiota composition on the pathogenesis of the disease remains elusive.

In this study, a combination of systems pharmacology and $16 \mathrm{~S}$ rRNA boosts our exploration of the potential relationship among drug-microbiota-target.

\section{Results}

In this study, a combination of oral bioavailability (OB) $(\geq 30 \%)$ screening, Caco-2 permeability (Caco-2) (>-0.4), prediction of permeability, half-life (HL) (long), and druglikeness $(\mathrm{DL})(\geq 0.18)$ properties was applied to explore the active compounds of SLBZS. We also added DL $<0.18$, $\mathrm{OB}<30 \%$, Caco $-2 \leq-0.4$, and $\mathrm{HL}=$ short with bioactivity as candidate compounds. Finally, we screened 97 SLBZS as candidate compounds (Table 1). The number of active compounds in Dolicho LablabL, Atractylodes macrocephala, Wolfiporia cocos, Glycyrrhiza uralensis Fisch, Platycodon grandiflorus, Semen Nelumbinis, Panax Ginseng, Fructus Amomi, Dioscorea opposita, and Semen Coicis was 4, 7, 15, $20,3,8,23,9,10$, and 8 , respectively.

2.1. Target Identification and Network Analysis. SLBZS exerts a pharmacological effect by targeting several host molecules $[15,16]$. To identify the drug-target direct interactions on a large scale, we hypothesized that the ensemble features of the ligand group can accurately reflect the direct binding information of a specific target based on ligand-target interaction data to establish the WES model. In the present study, 74 potential targets were predicted for the 97 candidate compounds (Supp Table S1 and S2).

\subsection{Network Construction}

2.2.1. Compound-Target Network. The compounds from SLBZS acted on multiple targets, and each target was involved with a variety of compounds. Figure 1(a) shows that the compound-target network contains 171 nodes and 330 compound-target interactions. We screened 74 target proteins from the potential target list related to intestinal disease processes, including inflammatory bowel disease, duodenal ulcer, and colitis. Additionally, multiple relationships between the compounds and targets were illustrated in this network. For instance, quercetin exhibited the highest number of target candidate-target interactions (degree $=28$ ), followed by luteolin $($ degree $=7)$ and kaempferol (degree $=15)$, thereby indicating the multitarget properties of SLBZS ingredients.

2.2.2. Target-Disease Network. To identify the relationship between SLBZS and disease, the DrugBank, TTD, and PharmGKB databases were searched. As shown in Figure 1(b) and Supp Table S3, 73 SLBZS compounds were related to 4 types of diseases, including digestive system disease $($ degree $=44)$, pathology processes $($ degree $=28)$, signs and symptoms $($ degree $=10)$, and cancer $($ degree $=19)$.

2.2.3. Target-Pathway Network. A total of 59 candidate targets and 47 KEGG pathways constituted the target-pathway network (Figure $1(\mathrm{c})$ ). Apparently, most targets were related to different pathways, indicating that SLBZS may exert synergistic effects through these different pathways. Additionally, one active compound may target different molecular targets, illustrating the multitarget mechanism of SLBZS. Moreover, to investigate the synergic effects of these 10 herbal medicines on IBD, an integrated "digestive-related pathway" approach was applied based on the current research of digestive disease pathology including the MAPK signaling pathway, NF-kappa B signaling pathway, calcium signaling pathway, and chemokine signaling pathway (Figure 2 and Supp Table S4 and S5).

2.2.4. Target Tissue Location. Supp Figure S1 shows the tissue location network based on these 70 targets, which can be divided into six tissue modules, including the liver, heart, spleen, lung, kidney, and gut. Thus, the candidate compounds reflect multiple targets that can be localized to more than one tissue (Supp Table S6).

2.3. Structural Changes of Intestinal Microbiota by SLBZS. To analyze the alteration in the intestinal microbiota structure in rats treated with herbal medicine for IBD, the Illumina sequencing system was used to generate high-quality sequences from stool samples. The $\alpha$ diversity of the intestinal microflora indicates that DSS can significantly decrease the Chaol and Shannon diversity indices in both experimental groups (MOD and SLBZS), whereas the SLBZS group showed a higher Shannon index when compared to the Chaol index after treatment with SLBZS (Figures 3(a)-3(d)). Principal component analysis (PCA) and principal coordinate analysis (PCoA) showed that SLBZS significantly altered the intestinal microbiota structure of rats (Figures 3(e) and 3(f)). Similarly, the unweighted UniFrac distance and unweighted pair-group method with arithmetic means (UPGMA) showed that DSS and SLBZS treatment can clearly separate rats (Figures 3(g) and $3(\mathrm{~h}))$.

To find key system types related to the efficacy of SLBZS, MetaStat analysis was used in this study. Using mothur software, the statistical algorithm of MetaStat [17] was used to perform a pairwise comparison test on the differences between the samples (groups) of each taxon at the gate and genus levels. A detailed phylogenetic analysis of the taxonomic composition of the microbiome of mice treated with DSS showed that the increased inflammatory conditions observed upon DSS administration were associated with variations in the abundance of specific taxa, including Firmicutes, Bacteroidetes, Proteobacteria, and Actinobacteria $[18,19]$ (Figure 4(a)).

Significant changes towards restoration of normobiosis were detected among the less abundant genera belonging to the Firmicutes phylum in the DSS+SLBZS-derived microbiota. For instance, Corynebacteriaceae, Lactobacillaceae, Paraprevotellaceae, Veillonellaceae, Prevotellaceae, and Clostridiaceae which were expanded in colitic rats were reduced upon SLBZS treatment and returned to levels comparable to those observed in control group rats (Figure 4(b)).

SLBZS-derived samples showed significant increases in known commensals, including Adlercreutzia and Dorea, and in the SCFA-producing taxa Ruminococcus spp., Blautia 
TABLE 1: Candidate information.

\begin{tabular}{|c|c|c|c|c|c|c|c|c|}
\hline No. & Compound & Herb & OB & Caco-2 & $\mathrm{HL}$ & $\mathrm{DL}$ & Degree & Structure \\
\hline MOL1 & Luteolin & $\begin{array}{l}\text { Platycodon } \\
\text { grandiflorus } \\
\text { Semen } \\
\text { Nelumbinis }\end{array}$ & 36.16 & 0.19 & Long & 0.25 & 17 & \\
\hline MOL2 & $\begin{array}{l}\text { 12-Senecioyl-2E,8E, } \\
10 \mathrm{E} \text {-atractylentriol }\end{array}$ & $\begin{array}{l}\text { Atractylodes } \\
\text { macrocephala }\end{array}$ & 62.40 & 0.01 & Short & 0.22 & 2 & \\
\hline MOL3 & $\begin{array}{l}\text { 14-Acetyl-12-senecioyl- } \\
\text { 2E,8E,10E-atractylentriol }\end{array}$ & $\begin{array}{l}\text { Atractylodes } \\
\text { macrocephala }\end{array}$ & 60.31 & 0.33 & Short & 0.31 & 1 & \\
\hline
\end{tabular}

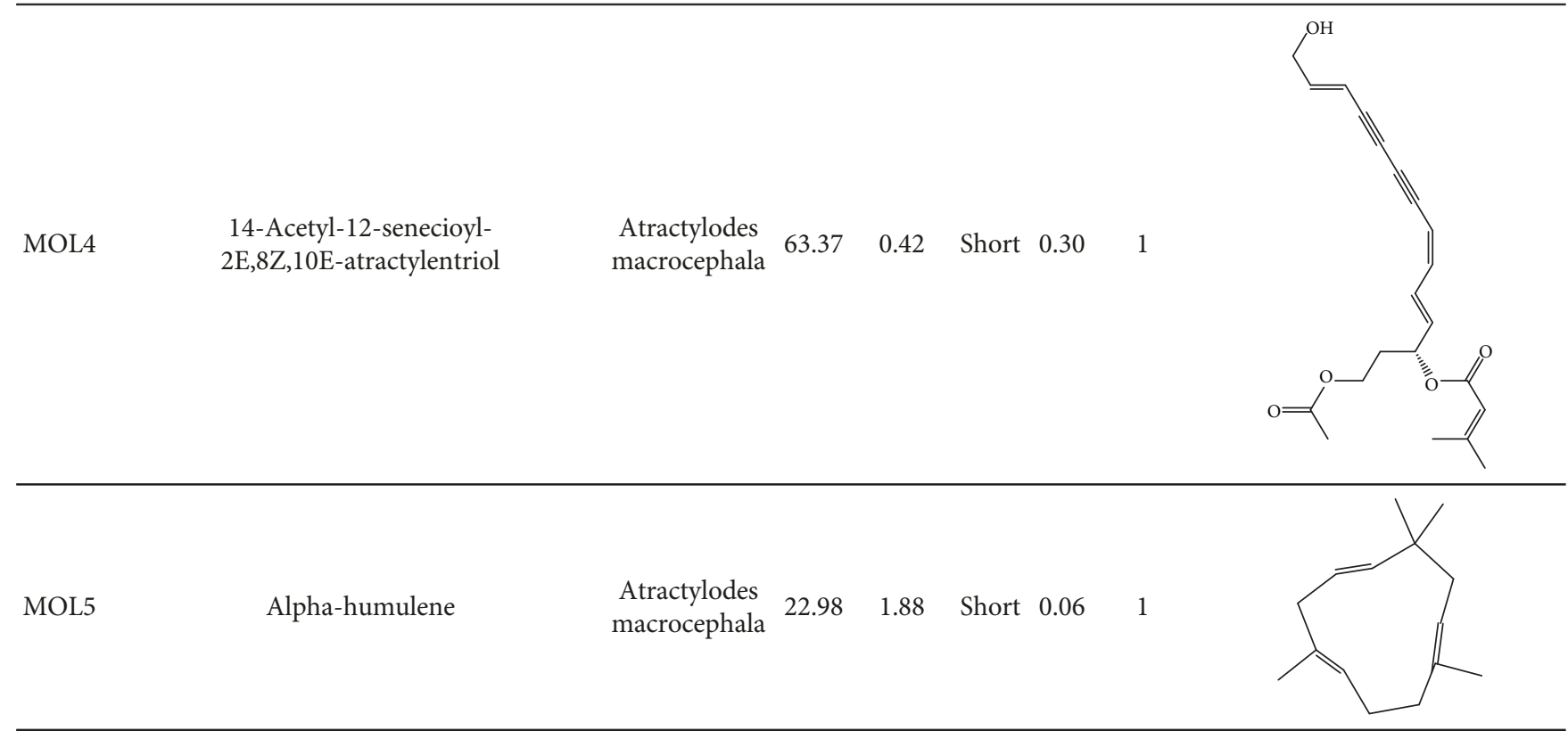


TABLe 1: Continued.

\begin{tabular}{|c|c|c|c|c|c|c|c|c|}
\hline No. & Compound & Herb & $\mathrm{OB}$ & Caco-2 & $\mathrm{HL}$ & $\mathrm{DL}$ & Degree & Structure \\
\hline MOL6 & $\begin{array}{c}\text { (3S,8S,9S,10R,13R,14S,17R)- } \\
\text { 10,13-Dimethyl-17-[(2R,5S)- } \\
\text { 5-propan-2-yloctan-2-yl]- } \\
\text { 2,3,4,7,8,9,11,12,14,15,16,17- } \\
\text { dodecahydro-1H- } \\
\text { cyclopenta[a]phenanthren-3-ol }\end{array}$ & $\begin{array}{l}\text { Atractylodes } \\
\text { macrocephala }\end{array}$ & 36.23 & 1.45 & Long & 0.78 & 3 & \\
\hline MOL7 & Atractylenolide I & $\begin{array}{l}\text { Atractylodes } \\
\text { macrocephala }\end{array}$ & 37.37 & 1.30 & Long & 0.15 & 2 & \\
\hline MOL8 & $3 \beta$-Acetoxyatractylone & $\begin{array}{l}\text { Atractylodes } \\
\text { macrocephala }\end{array}$ & 54.07 & 1.13 & Long & 0.22 & 2 & \\
\hline MOL9 & Palmitic acid & $\begin{array}{l}\text { Dolicho } \\
\text { LablabL }\end{array}$ & 19.30 & 1.09 & Short & 0.10 & 4 & \\
\hline MOL10 & Quercetin & $\begin{array}{l}\text { Glycyrrhiza } \\
\text { uralensis } \\
\text { Fisch } \\
\text { Semen } \\
\text { Nelumbinis }\end{array}$ & 46.43 & 0.05 & Short & 0.28 & 28 & \\
\hline MOL11 & Linoleic acid & $\begin{array}{l}\text { Dolicho } \\
\text { LablabL }\end{array}$ & 41.90 & 1.16 & Short & 0.14 & 3 & \\
\hline MOL12 & $\begin{array}{c}\text { (2R)-2-[(3S,5R,10S,13R,14R,16R,17R)- } \\
\text { 3,16-Dihydroxy-4,4,10,13,14- } \\
\text { pentamethyl-2,3,5,6,12,15,16,17- } \\
\text { octahydro-1H- } \\
\text { cyclopenta[a]phenanthren-17-yl]-6- } \\
\text { methylhept-5-enoic acid }\end{array}$ & $\begin{array}{l}\text { Wolfiporia } \\
\text { cocos }\end{array}$ & 30.93 & 0.01 & Short & 0.81 & 4 & \\
\hline MOL13 & Trametenolic acid & $\begin{array}{l}\text { Wolfiporia } \\
\text { cocos }\end{array}$ & 38.71 & 0.52 & Short & 0.80 & 2 & \\
\hline MOL14 & $\begin{array}{c}\text { 7,9(11)-Dehydropachymic } \\
\text { acid }\end{array}$ & $\begin{array}{l}\text { Wolfiporia } \\
\text { cocos }\end{array}$ & 35.11 & 0.03 & Short & 0.81 & 7 & \\
\hline
\end{tabular}


TABle 1: Continued.

\begin{tabular}{|c|c|c|c|c|c|c|c|c|}
\hline No. & Compound & Herb & OB & Caco-2 & $\mathrm{HL}$ & $\mathrm{DL}$ & Degree & Structure \\
\hline MOL15 & Cerevisterol & $\begin{array}{l}\text { Wolfiporia } \\
\text { cocos }\end{array}$ & 37.96 & 0.28 & Long & 0.77 & 2 & \\
\hline MOL16 & $\begin{array}{c}\text { (2R)-2-[(3S,5R,10S,13R,14R,16R,17R)- } \\
\text { 3,16-Dihydroxy-4,4,10,13,14- } \\
\text { pentamethyl-2,3,5,6,12,15, } \\
\text { 16,17-octahydro-1H- } \\
\text { cyclopenta[a]phenanthren-17-yl]- } \\
\text { 5-isopropyl-hex-5-enoic acid }\end{array}$ & $\begin{array}{c}\text { Wolfiporia } \\
\text { cocos }\end{array}$ & 31.07 & 0.05 & Short & 0.82 & 5 & \\
\hline MOL17 & Ergosta-7,22E-dien-3beta-ol & $\begin{array}{l}\text { Wolfiporia } \\
\text { cocos }\end{array}$ & 43.51 & 1.32 & Short & 0.72 & 1 & \\
\hline MOL18 & $\begin{array}{c}\text { (2R)-2-[(5R,10S,13R,14R,16R,17R)- } \\
\text { 16-Hydroxy-3-keto-4,4,10,13,14- } \\
\text { pentamethyl-1,2,5,6,12,15,16,17- } \\
\text { octahydrocyclopenta[a]phenanthren- } \\
\text { 17-yl]-5-isopropyl-hex-5-enoic acid }\end{array}$ & $\begin{array}{l}\text { Wolfiporia } \\
\text { cocos }\end{array}$ & 38.26 & 0.12 & Short & 0.82 & 5 & \\
\hline MOL19 & $\begin{array}{l}\text { 3beta-hydroxy-24-methylene- } \\
\text { 8-lanostene-21-oic acid }\end{array}$ & $\begin{array}{l}\text { Wolfiporia } \\
\text { cocos }\end{array}$ & 38.70 & 0.61 & Short & 0.81 & 2 & \\
\hline MOL20 & Pachymic acid & $\begin{array}{l}\text { Wolfiporia } \\
\text { cocos }\end{array}$ & 33.63 & 0.10 & Short & 0.81 & 4 & \\
\hline MOL21 & Poricoic acid A & $\begin{array}{l}\text { Wolfiporia } \\
\text { cocos }\end{array}$ & 30.61 & -0.14 & Short & 0.76 & 5 & \\
\hline MOL22 & Poricoic acid B & $\begin{array}{c}\text { Wolfiporia } \\
\text { cocos }\end{array}$ & 30.52 & -0.08 & Short & 0.75 & 4 & \\
\hline
\end{tabular}


TABle 1: Continued.

\begin{tabular}{|c|c|c|c|c|c|c|c|c|}
\hline No. & Compound & Herb & $\mathrm{OB}$ & Caco-2 & $\mathrm{HL}$ & $\mathrm{DL}$ & Degree & Structure \\
\hline MOL23 & Poricoic acid $\mathrm{C}$ & $\begin{array}{l}\text { Wolfiporia } \\
\text { cocos }\end{array}$ & 38.15 & 0.32 & Short & 0.75 & 4 & \\
\hline MOL24 & Hederagenin & $\begin{array}{l}\text { Wolfiporia } \\
\text { cocos }\end{array}$ & 36.91 & 1.32 & Short & 0.75 & 3 & \\
\hline MOL25 & Tumulosic acid & $\begin{array}{c}\text { Wolfiporia } \\
\text { cocos }\end{array}$ & 29.88 & 0.13 & Short & 0.81 & 2 & \\
\hline MOL26 & Dehydroeburicoic acid & $\begin{array}{l}\text { Wolfiporia } \\
\text { cocos }\end{array}$ & 44.17 & 0.38 & Short & 0.83 & 3 & \\
\hline MOL27 & Denudatin B & $\begin{array}{c}\text { Dioscorea } \\
\text { opposita }\end{array}$ & 61.47 & 0.90 & Long & 0.38 & 2 & \\
\hline MOL28 & Beta-sitosterol & $\begin{array}{c}\text { Panax } \\
\text { Ginseng } \\
\text { Fructus } \\
\text { Amomi }\end{array}$ & 36.91 & 1.32 & Short & 0.75 & 3 & \\
\hline MOL29 & Sitosterol & $\begin{array}{c}\text { Glycyrrhiza } \\
\text { uralensis } \\
\text { Fisch }\end{array}$ & 36.91 & 1.32 & Short & 0.75 & 2 & \\
\hline MOL30 & Docosanoic acid & $\begin{array}{l}\text { Dolicho } \\
\text { LablabL }\end{array}$ & 15.69 & 1.21 & Short & 0.26 & 1 & \\
\hline MOL31 & Rutin & $\begin{array}{l}\text { Glycyrrhiza } \\
\text { uralensis } \\
\text { Fisch } \\
\text { Semen } \\
\text { Nelumbinis }\end{array}$ & 3.20 & -1.93 & Long & 0.68 & 8 & \\
\hline
\end{tabular}


TABle 1: Continued.

\begin{tabular}{|c|c|c|c|c|c|c|c|c|}
\hline No. & Compound & Herb & OB & Caco-2 & $\mathrm{HL}$ & $\mathrm{DL}$ & Degree & Structure \\
\hline MOL32 & Kaempferol & $\begin{array}{l}\text { Glycyrrhiza } \\
\text { uralensis } \\
\text { Fisch } \\
\text { Panax } \\
\text { Ginseng }\end{array}$ & 41.88 & 0.26 & Long & 0.24 & 15 & \\
\hline MOL33 & Stigmasterol & $\begin{array}{c}\text { Panax } \\
\text { Ginseng } \\
\text { Fructus } \\
\text { Amomi } \\
\text { Dioscorea } \\
\text { opposita } \\
\text { Semen Coicis }\end{array}$ & 43.83 & 1.44 & Short & 0.76 & 1 & \\
\hline MOL34 & Licochalcone A & $\begin{array}{c}\text { Glycyrrhiza } \\
\text { uralensis } \\
\text { Fisch }\end{array}$ & 40.79 & 0.82 & Short & 0.29 & 2 & \\
\hline MOL35 & Cholesterol & $\begin{array}{c}\text { Dioscorea } \\
\text { opposita } \\
\text { Semen Coicis }\end{array}$ & 37.87 & 1.43 & Short & 0.68 & 3 & \\
\hline MOL36 & Sitosterol alpha1 & Semen Coicis & 43.28 & 1.41 & Short & 0.78 & 3 & \\
\hline MOL37 & Mandenol & Semen Coicis & 42.00 & 1.46 & Short & 0.19 & 4 & \\
\hline MOL38 & $\begin{array}{l}\text { 24-Ethylcholest-4- } \\
\text { en-3-one }\end{array}$ & $\begin{array}{l}\text { Fructus } \\
\text { Amomi }\end{array}$ & 36.08 & 1.46 & Short & 0.76 & 1 & \\
\hline MOL39 & $\begin{array}{l}\text { Poriferast-5-en- } \\
\text { 3beta-ol }\end{array}$ & $\begin{array}{l}\text { Fructus } \\
\text { Amomi }\end{array}$ & 36.91 & 1.45 & Short & 0.75 & 3 & \\
\hline
\end{tabular}


TABle 1: Continued.

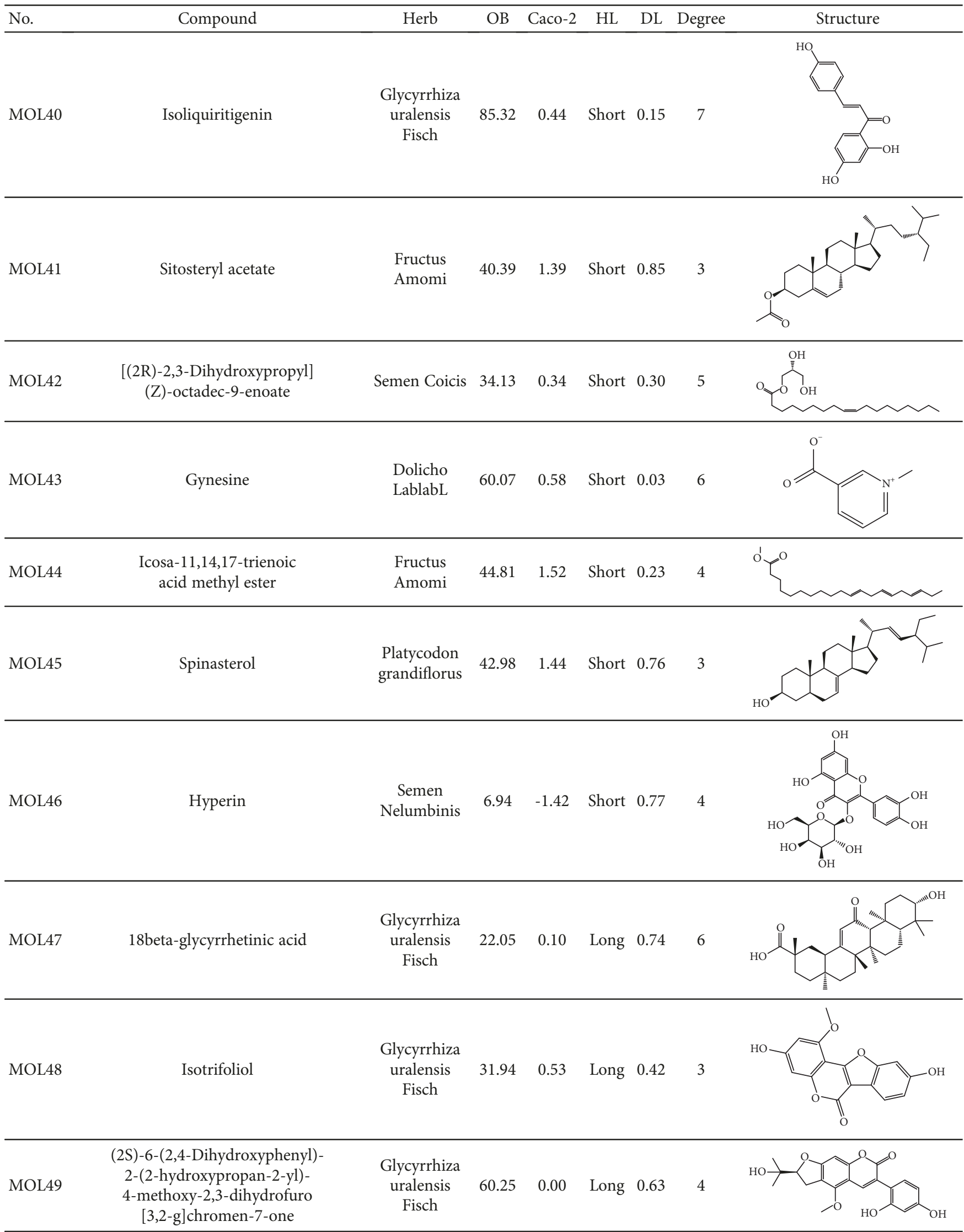


Table 1: Continued.

\begin{tabular}{|c|c|c|c|c|c|c|c|c|}
\hline No. & Compound & Herb & $\mathrm{OB}$ & Caco-2 & $\mathrm{HL}$ & $\mathrm{DL}$ & Degree & Structure \\
\hline MOL50 & Licochalcone B & $\begin{array}{c}\text { Glycyrrhiza } \\
\text { uralensis } \\
\text { Fisch }\end{array}$ & 76.76 & 0.47 & Short & 0.19 & 5 & \\
\hline MOL51 & Licochalcone C & $\begin{array}{c}\text { Glycyrrhiza } \\
\text { uralensis } \\
\text { Fisch }\end{array}$ & 4.44 & 0.63 & Long & 0.29 & 2 & \\
\hline MOL52 & Glycyrrhizic acid & $\begin{array}{c}\text { Glycyrrhiza } \\
\text { uralensis } \\
\text { Fisch }\end{array}$ & 19.62 & -2.66 & Long & 0.11 & 2 & \\
\hline MOL53 & Shinpterocarpin & $\begin{array}{c}\text { Glycyrrhiza } \\
\text { uralensis } \\
\text { Fisch }\end{array}$ & 80.30 & 1.10 & Long & 0.73 & 5 & \\
\hline MOL54 & Glabridin & $\begin{array}{c}\text { Glycyrrhiza } \\
\text { uralensis } \\
\text { Fisch }\end{array}$ & 53.25 & 0.97 & Long & 0.47 & 5 & \\
\hline MOL55 & Isoglycyrol & $\begin{array}{c}\text { Glycyrrhiza } \\
\text { uralensis } \\
\text { Fisch }\end{array}$ & 44.70 & 0.91 & Long & 0.84 & 1 & \\
\hline MOL56 & Icos-5-enoic acid & $\begin{array}{c}\text { Glycyrrhiza } \\
\text { uralensis } \\
\text { Fisch }\end{array}$ & 30.70 & 1.22 & Short & 0.20 & 3 & \\
\hline
\end{tabular}


TABLe 1: Continued.

\begin{tabular}{|c|c|c|c|c|c|c|c|c|}
\hline No. & Compound & Herb & $\mathrm{OB}$ & Caco-2 & $\mathrm{HL}$ & $\mathrm{DL}$ & Degree & Structure \\
\hline MOL57 & Gadelaidic acid & $\begin{array}{c}\text { Glycyrrhiza } \\
\text { uralensis } \\
\text { Fisch }\end{array}$ & 30.70 & 1.20 & Short & 0.20 & 2 & \\
\hline MOL58 & Gancaonin $\mathrm{H}$ & $\begin{array}{c}\text { Glycyrrhiza } \\
\text { uralensis } \\
\text { Fisch }\end{array}$ & 50.10 & 0.60 & Long & 0.78 & 8 & \\
\hline MOL59 & $\begin{array}{c}18 \alpha \text {-Hydroxyglycyrrhetic } \\
\text { acid }\end{array}$ & $\begin{array}{c}\text { Glycyrrhiza } \\
\text { uralensis } \\
\text { Fisch }\end{array}$ & 41.16 & -0.29 & Short & 0.71 & 2 & \\
\hline MOL60 & Xambioona & $\begin{array}{c}\text { Glycyrrhiza } \\
\text { uralensis } \\
\text { Fisch }\end{array}$ & 54.85 & 1.09 & Long & 0.87 & 3 & \\
\hline MOL61 & Deoxyharringtonine & $\begin{array}{c}\text { Panax } \\
\text { Ginseng }\end{array}$ & 39.27 & 0.19 & Short & 0.81 & 5 & \\
\hline MOL62 & Dianthramine & $\begin{array}{c}\text { Panax } \\
\text { Ginseng }\end{array}$ & 40.45 & -0.23 & Short & 0.20 & 3 & \\
\hline MOL63 & Arachidonate & $\begin{array}{c}\text { Panax } \\
\text { Ginseng }\end{array}$ & 45.57 & 1.27 & Short & 0.20 & 3 & \\
\hline
\end{tabular}


TABle 1: Continued.

\begin{tabular}{|c|c|c|c|c|c|c|c|c|}
\hline No. & Compound & Herb & $\mathrm{OB}$ & Caco-2 & $\mathrm{HL}$ & $\mathrm{DL}$ & Degree & Structure \\
\hline MOL64 & Ginsenoside Ro & $\begin{array}{c}\text { Panax } \\
\text { Ginseng }\end{array}$ & 1.98 & -2.86 & Long & 0.05 & 3 & \\
\hline MOL65 & Ginsenoside Rb1 & $\begin{array}{c}\text { Panax } \\
\text { Ginseng }\end{array}$ & 6.24 & -3.99 & Long & 0.04 & 2 & \\
\hline MOL66 & Ginsenoside-Rb2 & $\begin{array}{c}\text { Panax } \\
\text { Ginseng }\end{array}$ & 6.02 & -3.92 & Long & 0.04 & 2 & \\
\hline MOL67 & Ginsenoside-Rc & $\begin{array}{c}\text { Panax } \\
\text { Ginseng }\end{array}$ & 8.16 & -3.97 & Long & 0.04 & 2 & \\
\hline
\end{tabular}

MOL69


TABLe 1: Continued.

\begin{tabular}{|c|c|c|c|c|c|c|c|c|}
\hline No. & Compound & Herb & $\mathrm{OB}$ & Caco-2 & HL & $\mathrm{DL}$ & Degree & Structure \\
\hline MOL70 & Ginsenoside-Rh3_qt & $\begin{array}{c}\text { Panax } \\
\text { Ginseng }\end{array}$ & 13.09 & 0.97 & Long & 0.76 & 2 & \\
\hline MOL71 & Ginsenoside-Rh4 & $\begin{array}{c}\text { Panax } \\
\text { Ginseng }\end{array}$ & 5.22 & -0.73 & Short & 0.60 & 2 & \\
\hline MOL72 & Ginsenoside-Rh4_qt & $\begin{array}{c}\text { Panax } \\
\text { Ginseng }\end{array}$ & 31.11 & 0.50 & Short & 0.78 & 2 & \\
\hline MOL73 & Ginsenoside-Rs1 & $\begin{array}{c}\text { Panax } \\
\text { Ginseng }\end{array}$ & 6.27 & -3.69 & Long & 0.04 & 3 & \\
\hline MOL74 & Ginsenoside-Rs2 & $\begin{array}{c}\text { Panax } \\
\text { Ginseng }\end{array}$ & 8.14 & -4.03 & Short & 0.04 & 3 & \\
\hline MOL75 & Gomisin B & $\begin{array}{c}\text { Panax } \\
\text { Ginseng }\end{array}$ & 31.99 & 0.60 & Long & 0.83 & 5 & \\
\hline MOL76 & Panaxadiol & $\begin{array}{c}\text { Panax } \\
\text { Ginseng }\end{array}$ & 33.09 & 0.82 & Long & 0.79 & 2 & \\
\hline
\end{tabular}


TABle 1: Continued.

\begin{tabular}{|c|c|c|c|c|c|c|c|c|}
\hline No. & Compound & Herb & $\mathrm{OB}$ & Caco-2 & $\mathrm{HL}$ & $\mathrm{DL}$ & Degree & Structure \\
\hline MOL77 & Panaxytriol & $\begin{array}{c}\text { Panax } \\
\text { Ginseng }\end{array}$ & 33.76 & 0.06 & Short & 0.13 & 3 & \\
\hline MOL78 & Alexandrin_qt & $\begin{array}{c}\text { Panax } \\
\text { Ginseng }\end{array}$ & 36.91 & 1.30 & Long & 0.75 & 1 & \\
\hline MOL79 & Ginsenoside Rg5 & $\begin{array}{c}\text { Panax } \\
\text { Ginseng }\end{array}$ & 6.15 & -1.92 & Long & 0.23 & 1 & \\
\hline MOL80 & Ginsenoside Rg5_qt & $\begin{array}{c}\text { Panax } \\
\text { Ginseng }\end{array}$ & 39.56 & 0.88 & Long & 0.79 & 2 & \\
\hline MOL81 & Hancinol & $\begin{array}{c}\text { Dioscorea } \\
\text { opposita }\end{array}$ & 64.01 & 0.53 & Long & 0.37 & 2 & \\
\hline MOL82 & Hancinone $\mathrm{C}$ & $\begin{array}{c}\text { Dioscorea } \\
\text { opposita }\end{array}$ & 59.05 & 0.74 & Long & 0.39 & 1 & \\
\hline MOL83 & $\begin{array}{l}\text { 24-Methylcholest- } \\
\text { 5-enyl-3belta-O- } \\
\text { glucopyranoside_qt }\end{array}$ & $\begin{array}{c}\text { Dioscorea } \\
\text { opposita }\end{array}$ & 37.58 & 1.33 & Short & 0.72 & 1 & \\
\hline MOL84 & Campesterol & $\begin{array}{c}\text { Dioscorea } \\
\text { opposita }\end{array}$ & 37.58 & 1.34 & Short & 0.71 & 1 & \\
\hline
\end{tabular}


TABle 1: Continued.

\begin{tabular}{|c|c|c|c|c|c|c|c|c|}
\hline No. & Compound & Herb & OB & Сaco-2 & $\mathrm{HL}$ & $\mathrm{DL}$ & Degree & Structure \\
\hline MOL85 & Isofucosterol & $\begin{array}{l}\text { Dioscorea } \\
\text { opposita }\end{array}$ & 43.78 & 1.36 & Short & 0.76 & 1 & \\
\hline MOL86 & Dioscoreside C_qt & $\begin{array}{l}\text { Dioscorea } \\
\text { opposita }\end{array}$ & 36.38 & 0.39 & Long & 0.87 & 2 & \\
\hline MOL87 & Doradexanthin & $\begin{array}{l}\text { Dioscorea } \\
\text { opposita }\end{array}$ & 38.16 & 0.52 & Short & 0.54 & 4 & \\
\hline MOL88 & Platycodin D & $\begin{array}{l}\text { Platycodon } \\
\text { grandiflorus }\end{array}$ & 7.60 & -4.99 & Long & 0.01 & 2 & \\
\hline MOL89 & Methyl icosa-11,14-dienoate & $\begin{array}{l}\text { Fructus } \\
\text { Amomi }\end{array}$ & 39.67 & 1.47 & Short & 0.23 & 3 & \\
\hline MOL90 & $\begin{array}{c}\text { (5S,8S,9S,10R,13R,14S,17R)- } \\
\text { 17-[(1R,4R)-4-Ethyl-1, } \\
\text { 5-dimethylhexyl]-10,13- } \\
\text { dimethyl-2,4,5,7,8,9,11, } \\
\text { 12,14,15,16,17-dodecahydro- } \\
\text { 1H-cyclopenta[a]phenanthrene- } \\
\text { 3,6-dione }\end{array}$ & $\begin{array}{l}\text { Fructus } \\
\text { Amomi }\end{array}$ & 33.12 & 0.90 & Short & 0.79 & 1 & \\
\hline MOL91 & $\begin{array}{l}\text { Stigmasta-5,22-dien-3-beta- } \\
\text { yl acetate }\end{array}$ & $\begin{array}{l}\text { Fructus } \\
\text { Amomi }\end{array}$ & 46.44 & 1.41 & Short & 0.86 & 3 & \\
\hline MOL92 & Coixenolide & Semen Coicis & 32.40 & 1.09 & Short & 0.43 & 1 & \\
\hline MOL93 & 2-Monoolein & Semen Coicis & 34.23 & 0.32 & Short & 0.29 & 2 & \\
\hline
\end{tabular}


TABLE 1: Continued.

\begin{tabular}{llllllll}
\hline No. & Compound & $\mathrm{Herb}$ & $\mathrm{OB}$ & $\mathrm{Caco}-2$ & $\mathrm{HL}$ & $\mathrm{DL}$ & Degree \\
\hline & & & & \\
MOL94 & Galuteolin & Semen & 2.70 & -1.50 & Short & 0.79
\end{tabular}

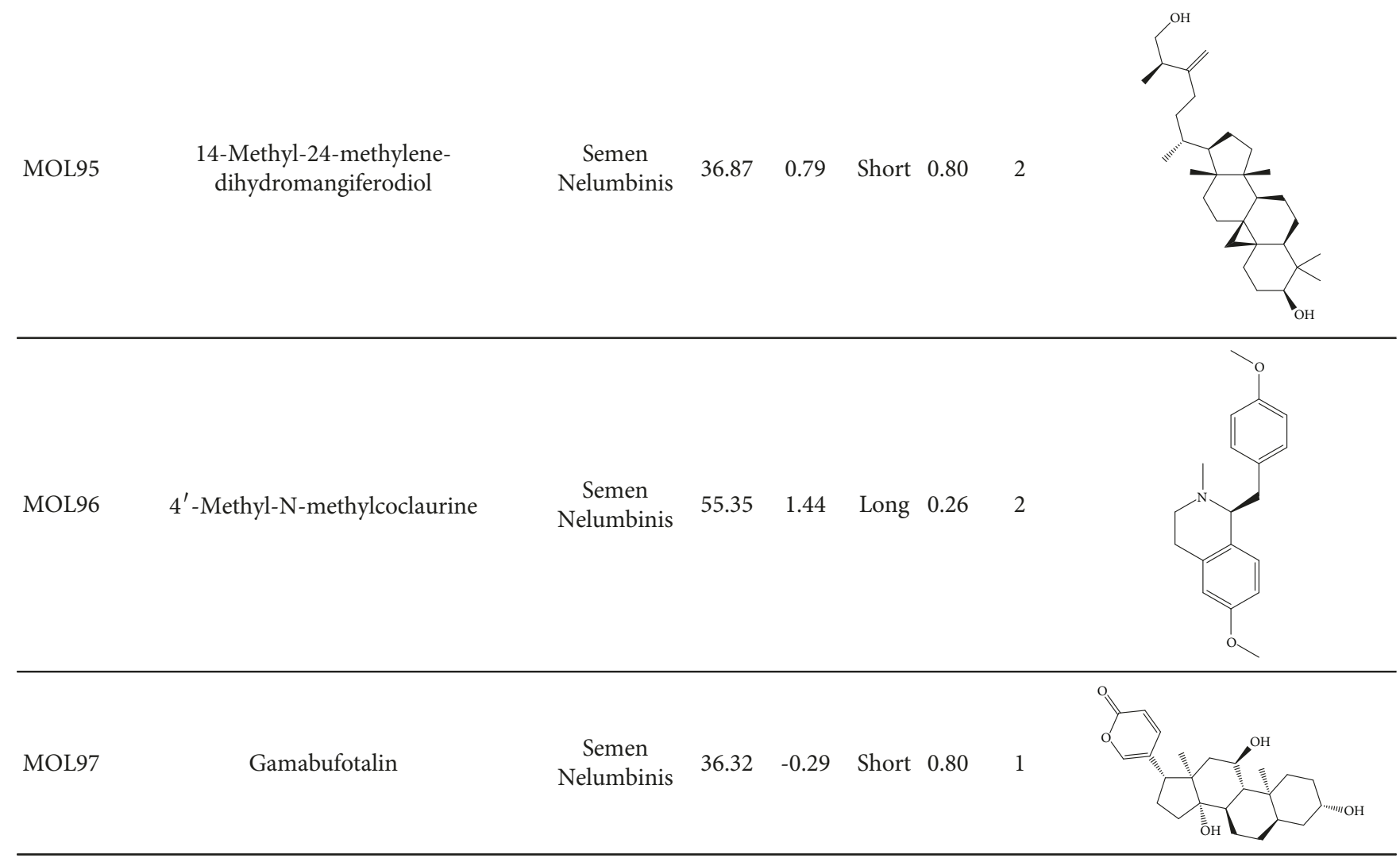

sp., Clostridium spp., Veillonella spp., Coprococcus spp., and Roseburia spp. (Figure 4(c) and Supp Figure S2), which are reported to be reduced in IBD patients [20-22]. Additionally, PICRUSt was applied to predict microbiota metabolism [23]. 328 pathways were involved in the microbiota metabolism and 176 pathways were significantly changed by SLBZS (Figure 5 and Supp Figure S3). After treatment with SLBZS, the relative abundance of functional genes in the following categories significantly $(P<0.01)$ increased: cell motility, signal transduction, membrane transport, and amino acid metabolism, all of which were reduced in the DSS-treated group. Meanwhile, cell growth and death, replication and repair, infectious diseases, immune system diseases, glycan biosynthesis and metabolism, and digestive system genes were significantly $(P<0.01)$ decreased but were increased in the DSS group.

2.4. Alleviation of IL-1 $\beta, I L-10$, and TNF- $\alpha$ and Pathological Changes by SLBZS. We analyzed the data from the experi- ment, and after one week of treatment, IL- $1 \beta$ and TNF- $\alpha$ were significantly decreased by SLBZS, whereas IL-10 was increased. As shown in Figures 6(a)-6(c), IL-1 $\beta$ and TNF- $\alpha$ were significantly decreased, while IL-10 increased after treatment with SLBZS. The histological changes in the colons of each group are shown in Figures 6(d)-6(f). The colon of the control group exhibited normal histological features. In the model group, there was infiltration of colon mucosal inflammatory cells, and the intestinal villus epithelial cells were degenerated, necrotic, and shed. Pathological changes were significantly reduced in the SLBZS group.

\section{Discussion}

To our knowledge, this is the first study to evaluate the efficacy of TCM on IBD with a systems pharmacology and microbiota approach. Chinese herbs are a complex system of multicomponent, multitarget, and synergistic effects among its components. This systematic pharmacological 


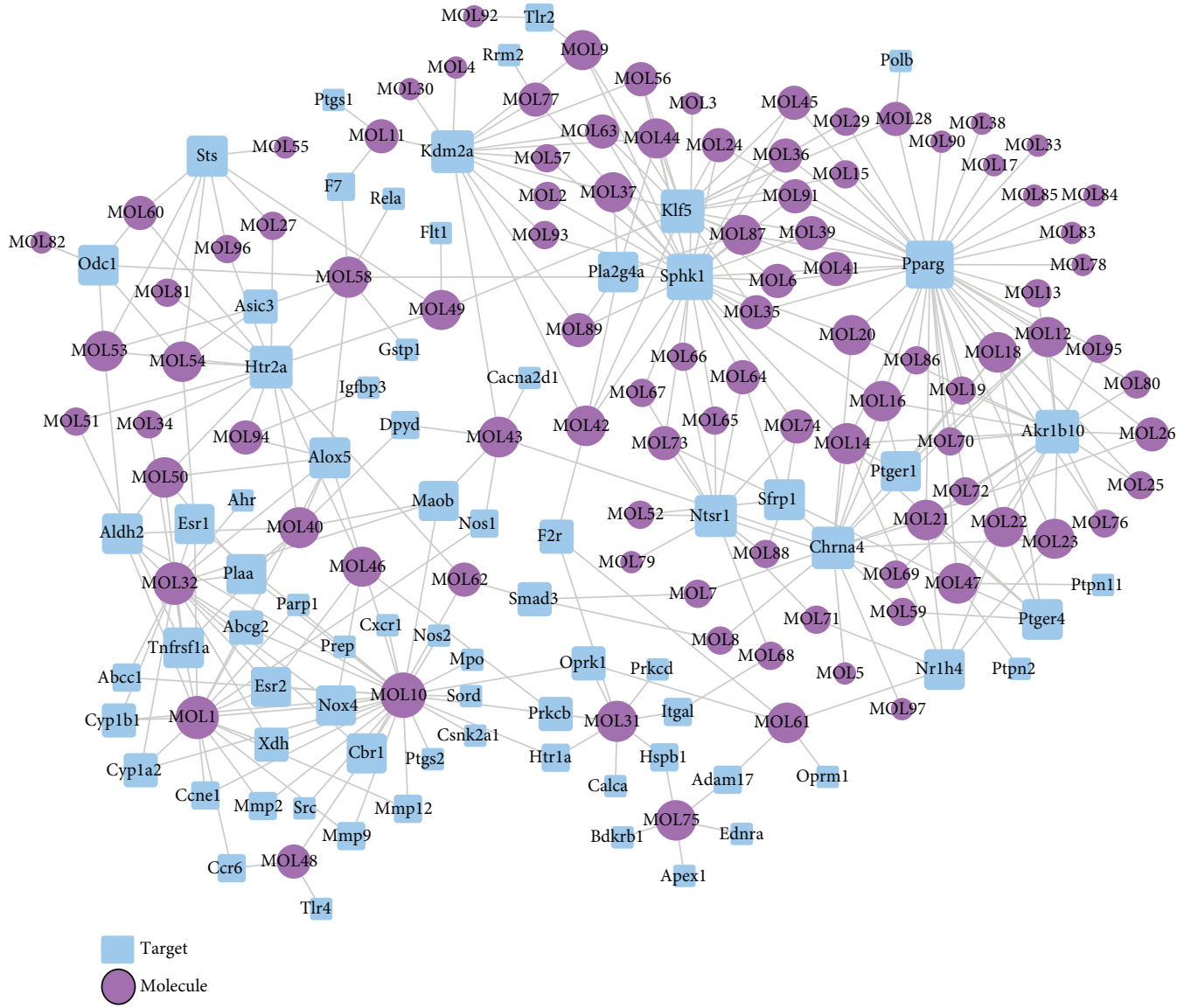

(a)

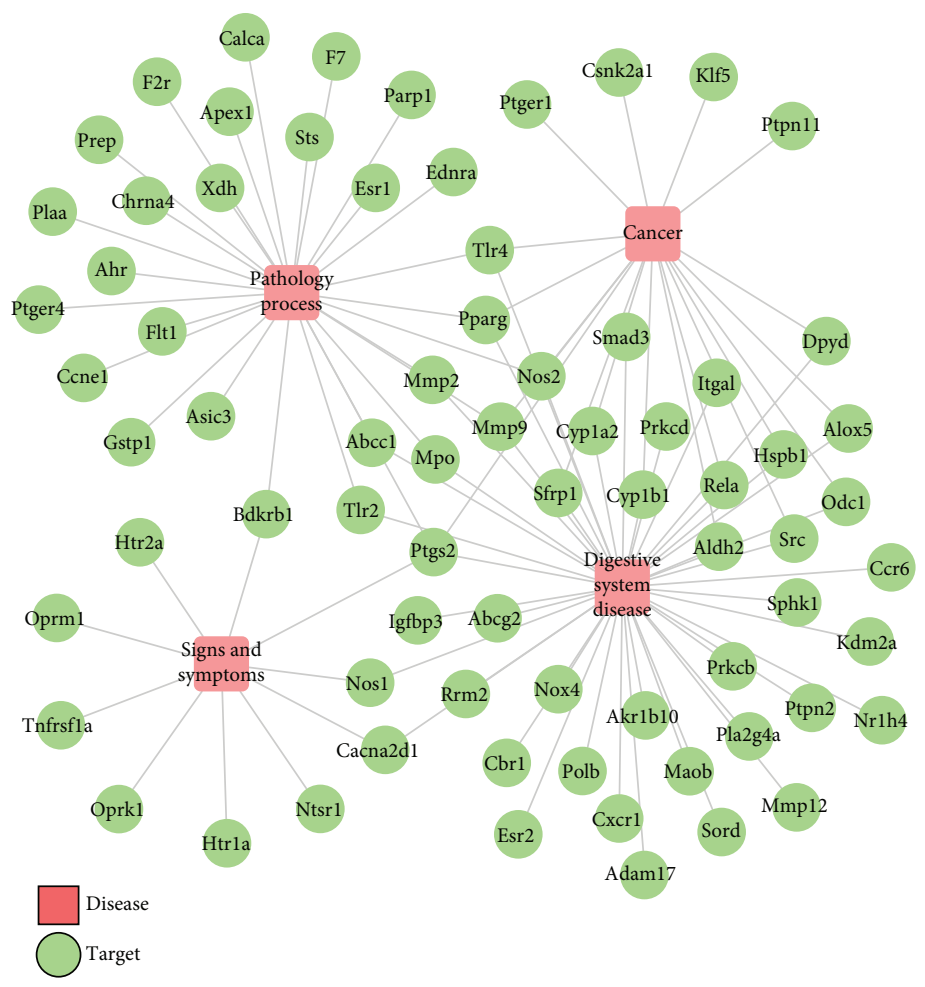

(b)

Figure 1: Continued. 


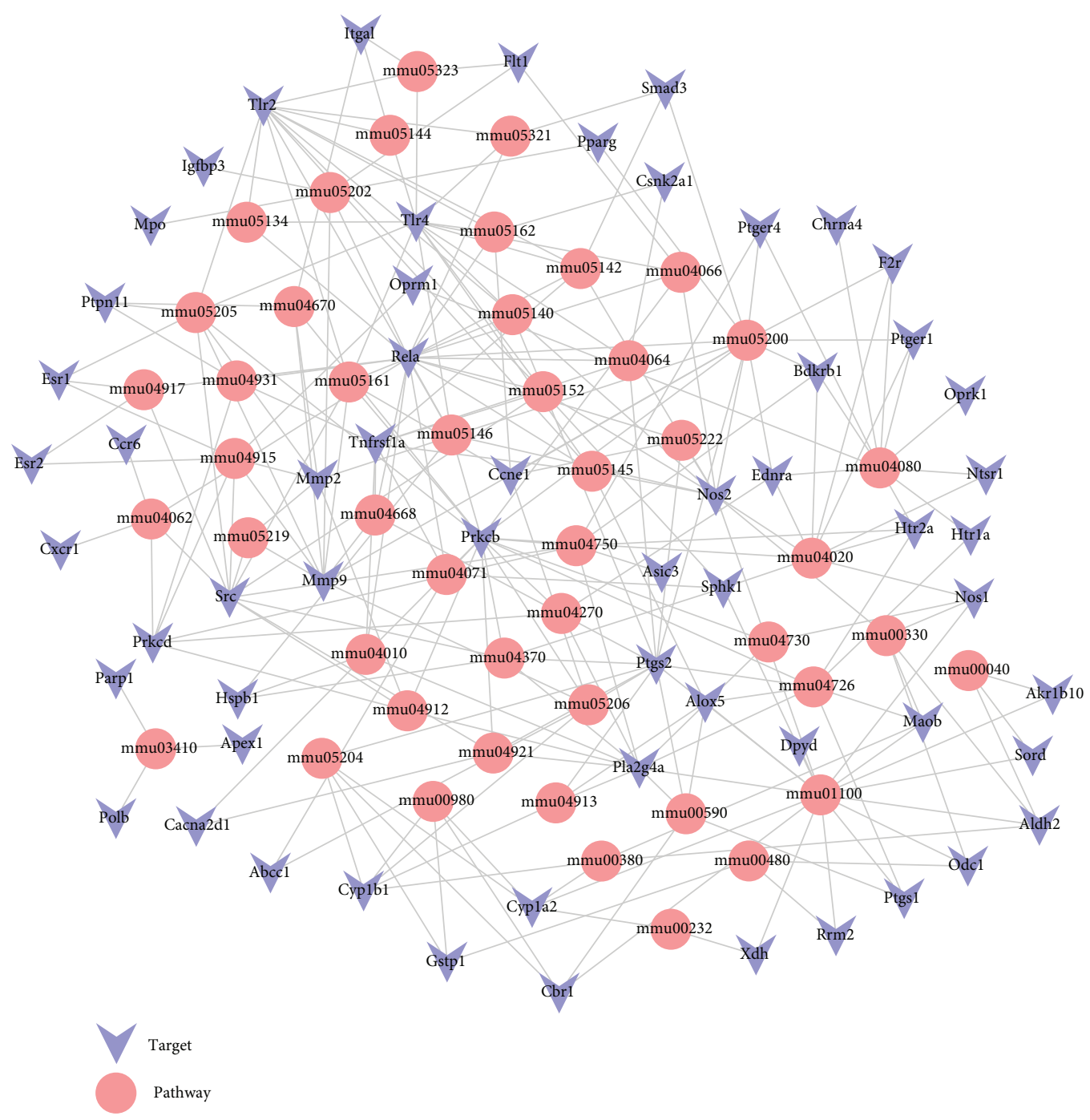

(c)

FIgURE 1: Compound-target-disease-pathway network. (a) Compound-target network of SLBZS consisting of 171 nodes (97 compounds and 74 potential targets) and 330 edges. (b) Target-disease network including 73 candidate targets and 4 diseases. (c) Target-pathway network including 59 candidate targets and 47 KEGG pathways.

technique is used to study TCM active compounds and target identification and identify targets and the relationship between drugs and diseases.

In this study, some herbal medicines may contain the same compound, such as Glycyrrhiza uralensis Fisch and Panax Ginseng, Panax Ginseng and Fructus Amomi, and Panax Ginseng and Glycyrrhiza uralensis Fisch. Among these, Atractylodes macrocephala, Glycyrrhiza uralensis Fisch, and Panax Ginseng have been found to have extensive pharmacological effects, such as antioxidant, immunomodulation, and anti-inflammatory [24-29]. In particular, the low molecular weight Glycyrrhiza uralensis Fisch can inhibit tumor cell proliferation to exert anticancer and immunomodulatory effects. They also increase the thymus/spleen index and T lymphocyte population. In addition, Glycyrrhiza uralensis Fisch can increase the expression of antitumor factors such as IL2, IL6, and IL7 and reduce the protumor cytokine TNF $\alpha$ [24]. Shimato et al. have demonstrated that Atractylodes macroce- phala can promote the production of G-CSF, clinically used to treat neutropenia and prevent chemotherapy-induced immunodeficiency [27]. Also, Panax Ginseng has been demonstrated to regulate multiple types of immune cells including macrophages, NK cells, DCs, T cells, and B cells [30]. Moreover, luteolin and quercetin, which existed widely in Glycyrrhiza uralensis Fisch, Platycodon grandiflorus, and Semen Nelumbinis, have been proven to have broad biological and pharmacological effects [31, 32].

Despite the different numbers of each herbal-related targets, significant target overlap occurred between these herbals. The results indicate that these targets can be regulated by different herbs in SLBZS to play a synergistic role $[15,16]$. For example, several compounds including alexandrin_qt, campesterol, isofucosterol, and panaxadiol were involved in modulating the activation of peroxisome proliferator-activated receptor gamma (Pparg), which might be ascribed to lipid and glucose metabolism [33, 34]. 


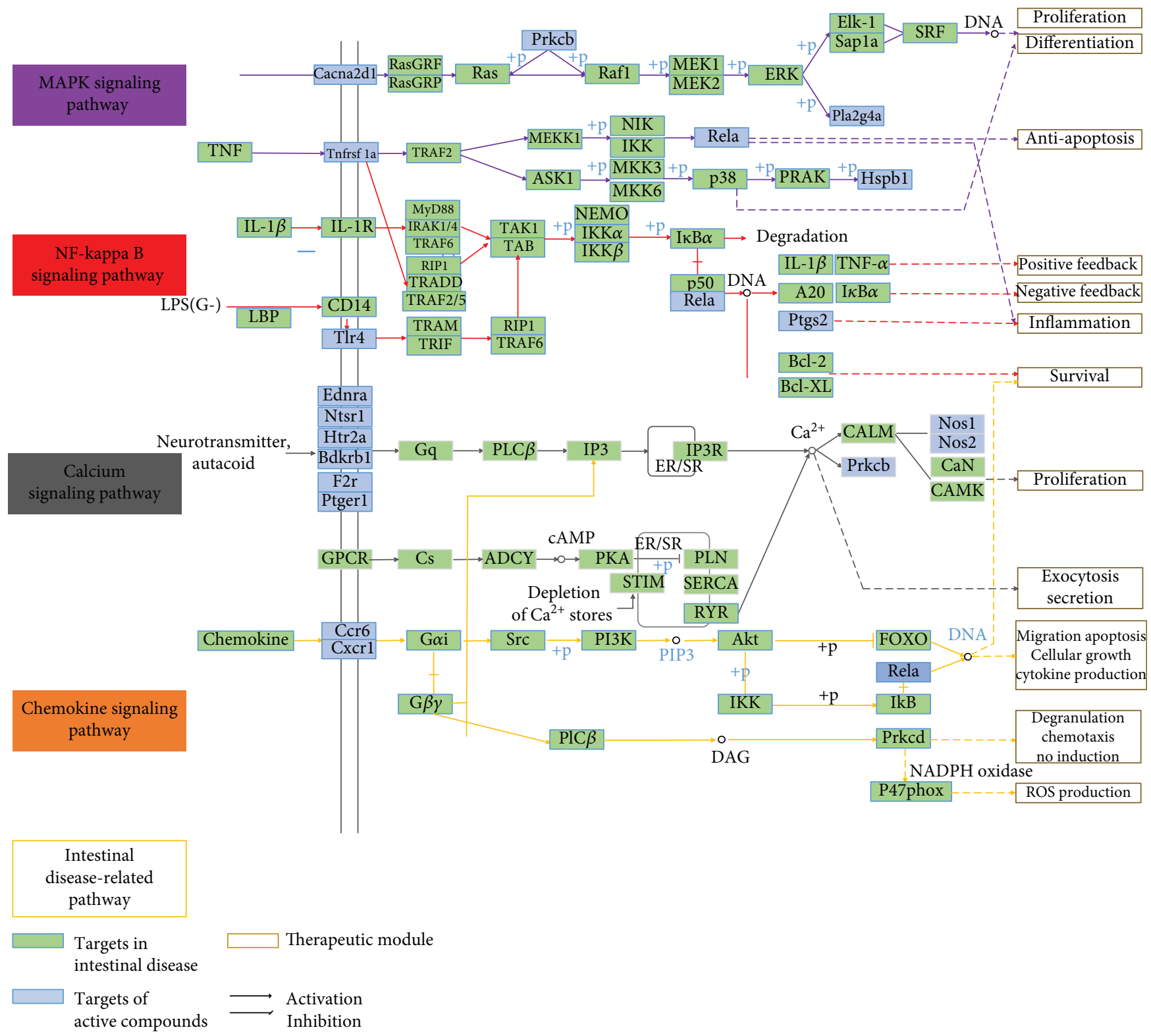

FIGURE 2: Intestinal disease-related pathway including MAPK signaling pathway, NF-kappa B signaling pathway, calcium signaling pathway, and chemokine signaling pathway.

Based on network construction, the results indicate that most compounds modulate multiple targets to exert their pharmacological effects. For example, quercetin exhibits not only antitumor [35] and anticancer [31] activity but also antiproliferative effects [36]. Antiproliferative effects of conjugated metabolites of quercetin have been evaluated against three different cancer cell lines [36]. In addition, luteolin presents anti-inflammatory effects, serves as a neuroprotective agent [37], and also exhibits antitumor effect [32, 38]. The antitumor effect of luteolin may be transmitted by cMet/ Akt/ERK signaling [38]. Furthermore, the results indicated that several targets are hit by multiple ingredients in the compound-target network. Pparg showed the highest degree $($ degree $=39$ ), along with Sphk1 (Sphingosine kinase 1 , degree =31), Klf5 (Kruppel-like factor 5, degree =19), and Akr1b10 (Aldo-keto reductase family 1 member B10, degree $=19$ ), demonstrating the potential therapeutic effect of each drug contained in SLBZS for combating intestinal disease via modulation of these relevant proteins. These targets play crucial pathological rules in disease related to cancer [39-42]. AKR1B10 has been shown to be closely related to tumor size and cell metastasis of gastric cancer, and AKR1B10 can be used as a good prognostic indicator for gastric cancer [39]. Deletion of KLF5 can result in a decrease in PI3K/AKT signaling and accumulate HIF1 $\alpha$ in prostate tumors to promote tumor angiogenesis [40]. Previous research has illustrated that the PPAR $\gamma$ allele may be involved in the development, differentiation, and metastasis of gastric cancer in Turkey [43]. Sphk1 has been shown to be involved in the pathogenesis of human hepatocellular 


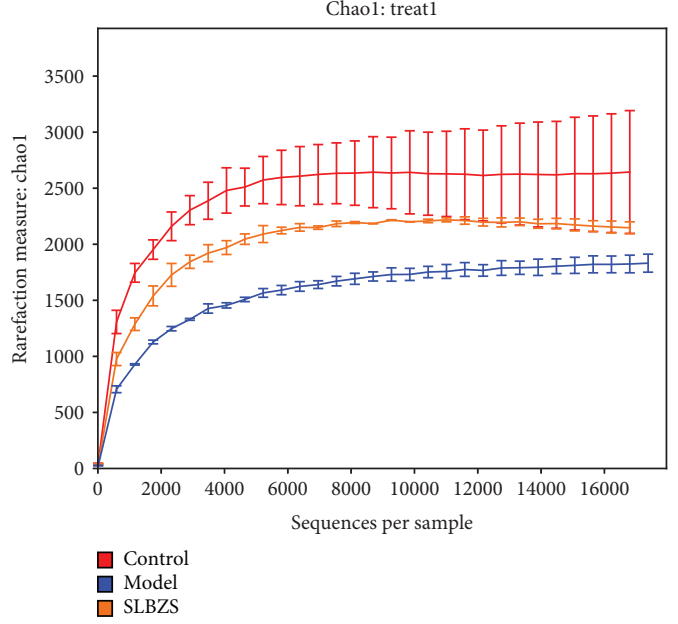

(a)

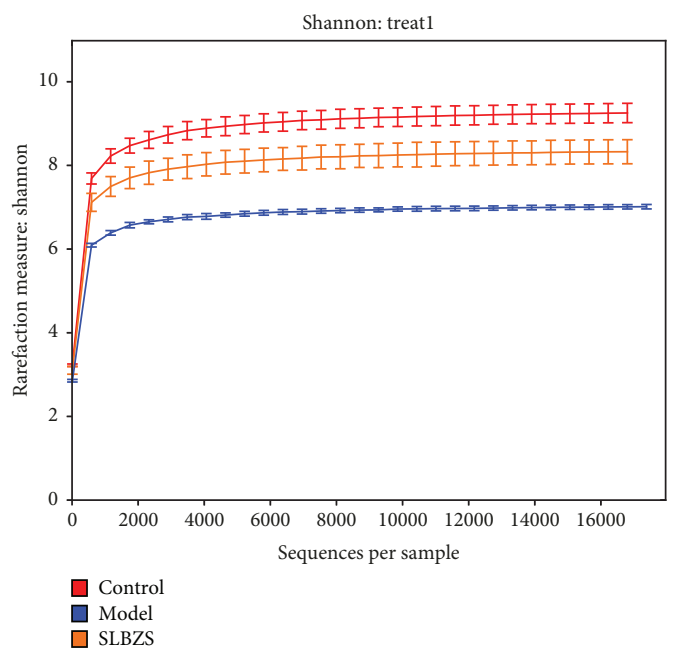

(c)

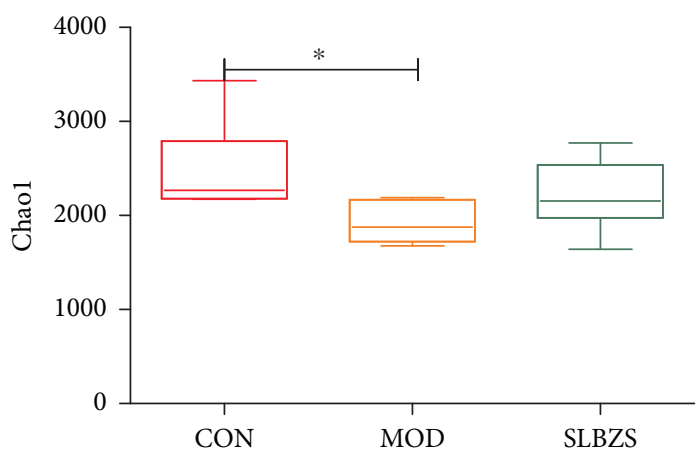

(b)

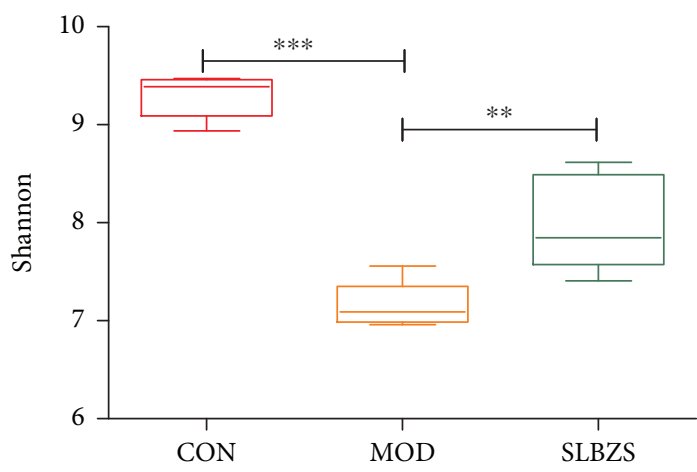

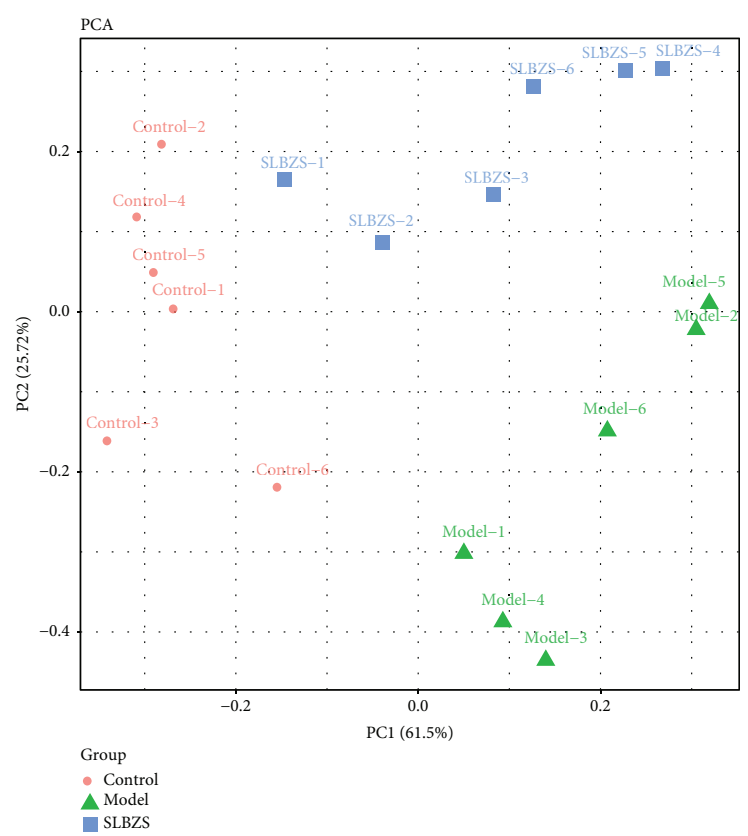

(e)

Figure 3: Continued. 


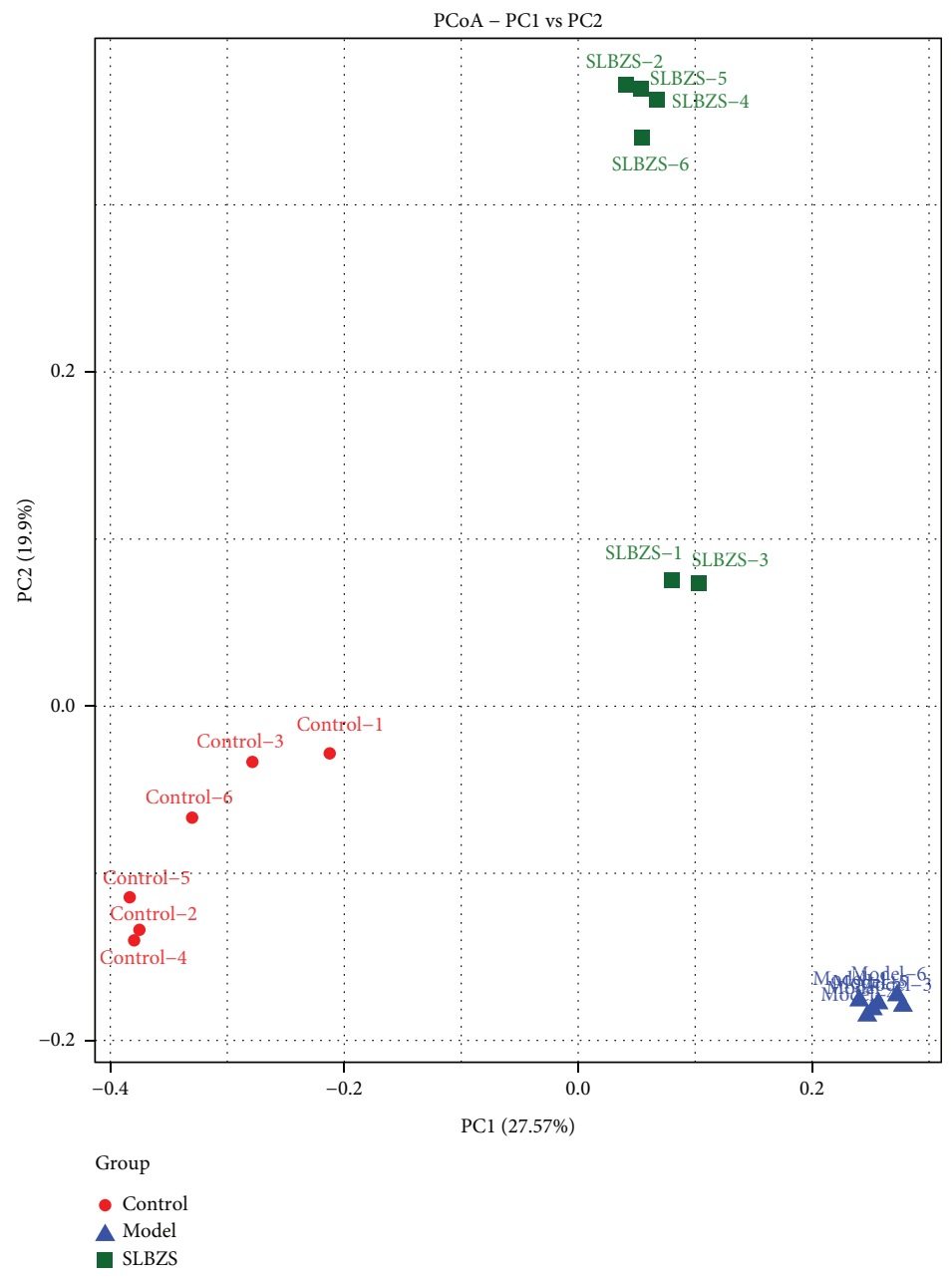

(f)

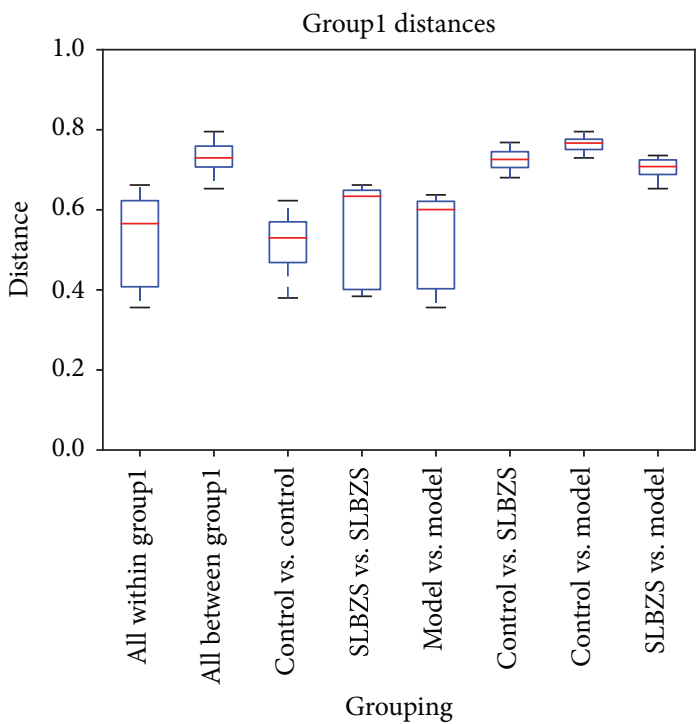

(g)

FIgURE 3: Continued. 


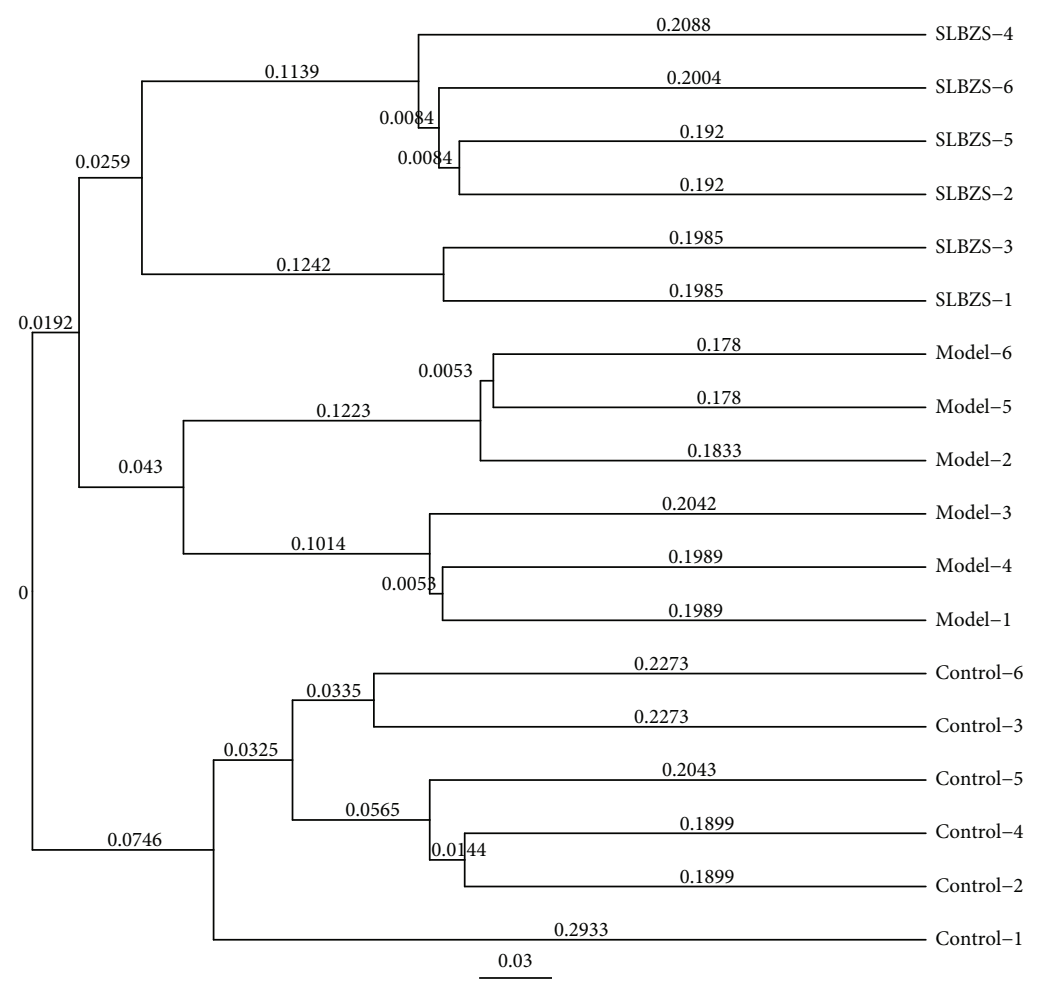

(h)

FIGURE 3: The effect on the gut microbiota structure of SLBZS. (a-d) Rarefaction curves showing microbial richness based on the Chao1 index and microbial richness and evenness on the Shannon index. (e, f) Microbiome clustering based on unweighted principal component analysis (PCA) and principal coordinate analysis (PCoA) UniFrac metrics of fecal gut microbiota. (g, h) Unweighted UniFrac distance and unweighted pair-group method with arithmetic means (UPGMA) showed that DSS and SLBZS treatment can separate rats clearly. Statistical significant difference was assessed through one-way ANOVA with LSD post hoc test ${ }^{*} P<0.05,{ }^{* *} P<0.01$, and ${ }^{* * *} P<0.001$; $n=6$.

carcinoma (HCC), and DMS can inhibit the effects of Sphk1. Therefore, Sphk1 can be used as a potential target for the treatment of HCC [42].

Reportedly, the proteins Mmp12, Pparg, and Ptgs2 are related to digestive system disease and cancer. Biancheri et al. demonstrated that Mmp12 contributes to the responsiveness of patients with IBD to anti-TNF agents [44] and might be involved in the remodeling of injured gut tissue with respect to the migration, proliferation, and differentiation of endothelial cells [45]. Pparg is involved in the inhibition of tissue damage associated with immune activation through the inhibition of the NF- $\kappa \mathrm{B}$ pathway [46]. Ptgs2 can repair the injured intestinal mucosa and exert a critical role in the pathophysiology of Salmonella typhimuriuminduced ulcerative colitis [47].

Some pathways, such as the NF- $\kappa$ B pathway [46], MAPK pathway [48, 49], calcium signaling pathway [50], and chemokine signaling pathway [51], have been improved in relation to digestive disease. In addition, these pathways are reflected in several modules such as inflammation, proliferation apoptosis, survival, and proliferation.

The MAPK cascade is a highly conserved module that is involved in various cellular functions, including cell proliferation, differentiation, and migration. A study on the pharmacological approach showed that stevioside exerts antiapoptotic and anti-inflammatory effects through the inhibition of the release of cytokines and the activation of the MAPK signaling pathway [52]. Another pharmacological study showed that berberine might execute an antiapoptotic function by inhibiting the MAPK pathway [53]. In macrophages, carbon monoxide $(\mathrm{CO})$ reduces lipopolysaccharideinduced proinflammatory cytokines effectuated by the MAPK pathway [48]. Recent studies have highlighted that oxidative stress activates MAPKs and MT2A (a mediator of MAPKs) that play a crucial role in antiapoptosis and antiinflammation [54]. Studies have shown that black raspberries (BRB) have a preventive effect on rat esophageal cancer, and the mechanism may be that $\mathrm{BRB}$ reverse oxidative stress and inhibit NF- $\kappa B / M A P K$ pathway [55]. Rutin exerts neuroprotective effects by increasing superoxide dismutase and glutathione peroxidase levels in the peripheral blood and inhibiting the p38 MAPK pathway [56]. This finding reveals the importance of MAPKs in the normal digestive function.

NF- $\kappa \mathrm{B}$ is found in almost all animal cell types and is involved in cellular responses to stimuli such as stress, cytokines, free radicals, heavy metals, ultraviolet irradiation, oxidized LDL, and bacterial or viral antigens. NF- $\kappa$ B also regulates the expression of antiapoptotic genes which play an important role in cell survival and play various roles in cell development, proliferation, differentiation, and metabolism [57]. Furthermore, the degree of NF- $\kappa \mathrm{B}$ activation induced by LPS is significantly increased in Atg7-deficient intestinal 


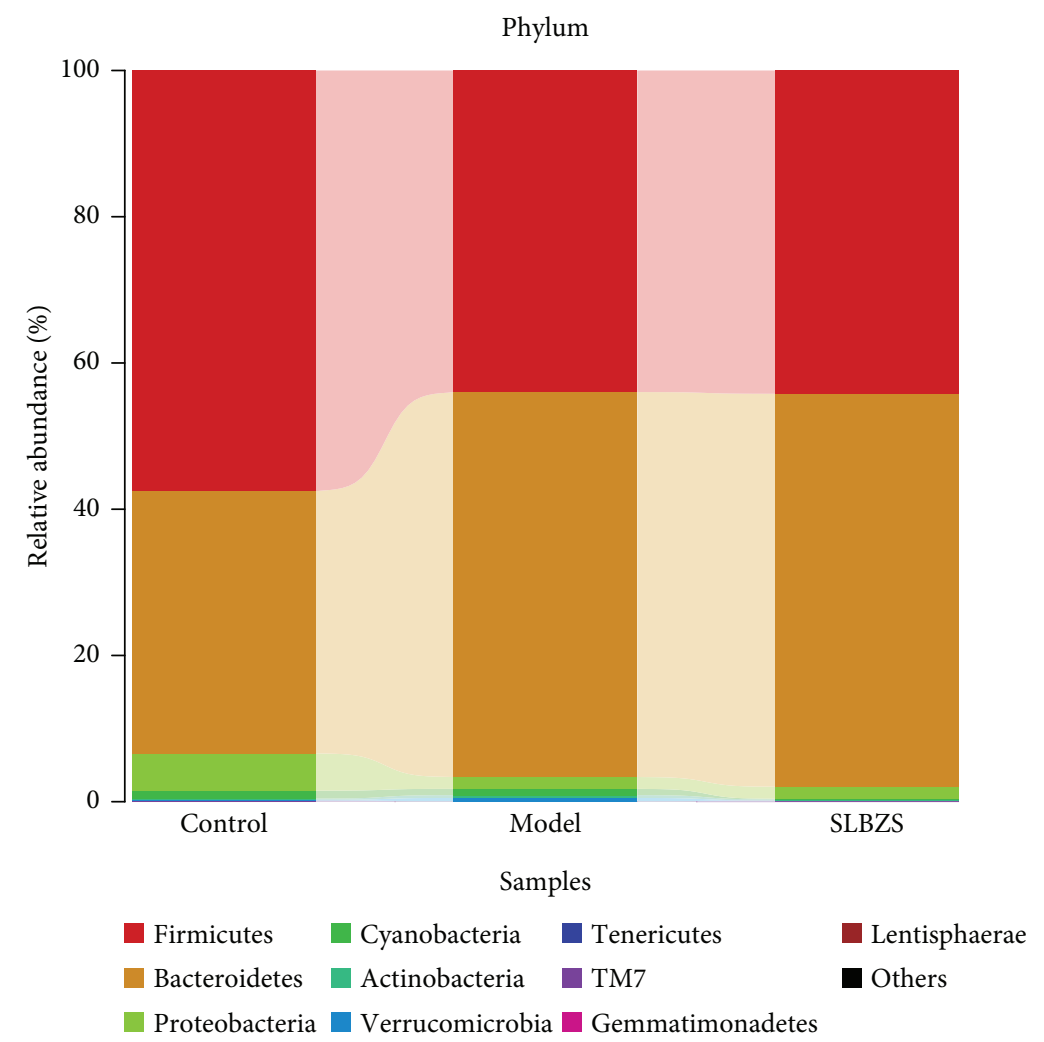

(a)

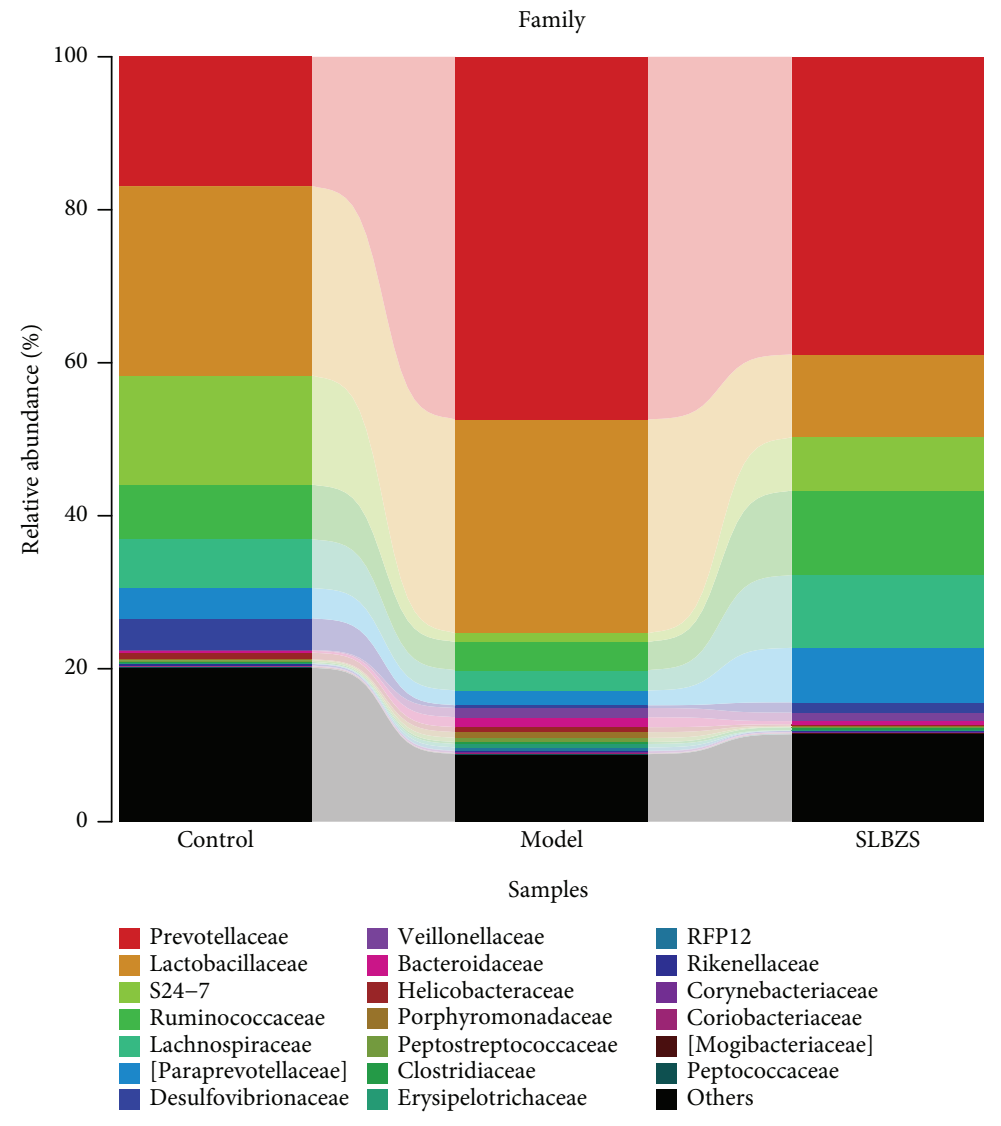

(b)

FIgURe 4: Continued. 


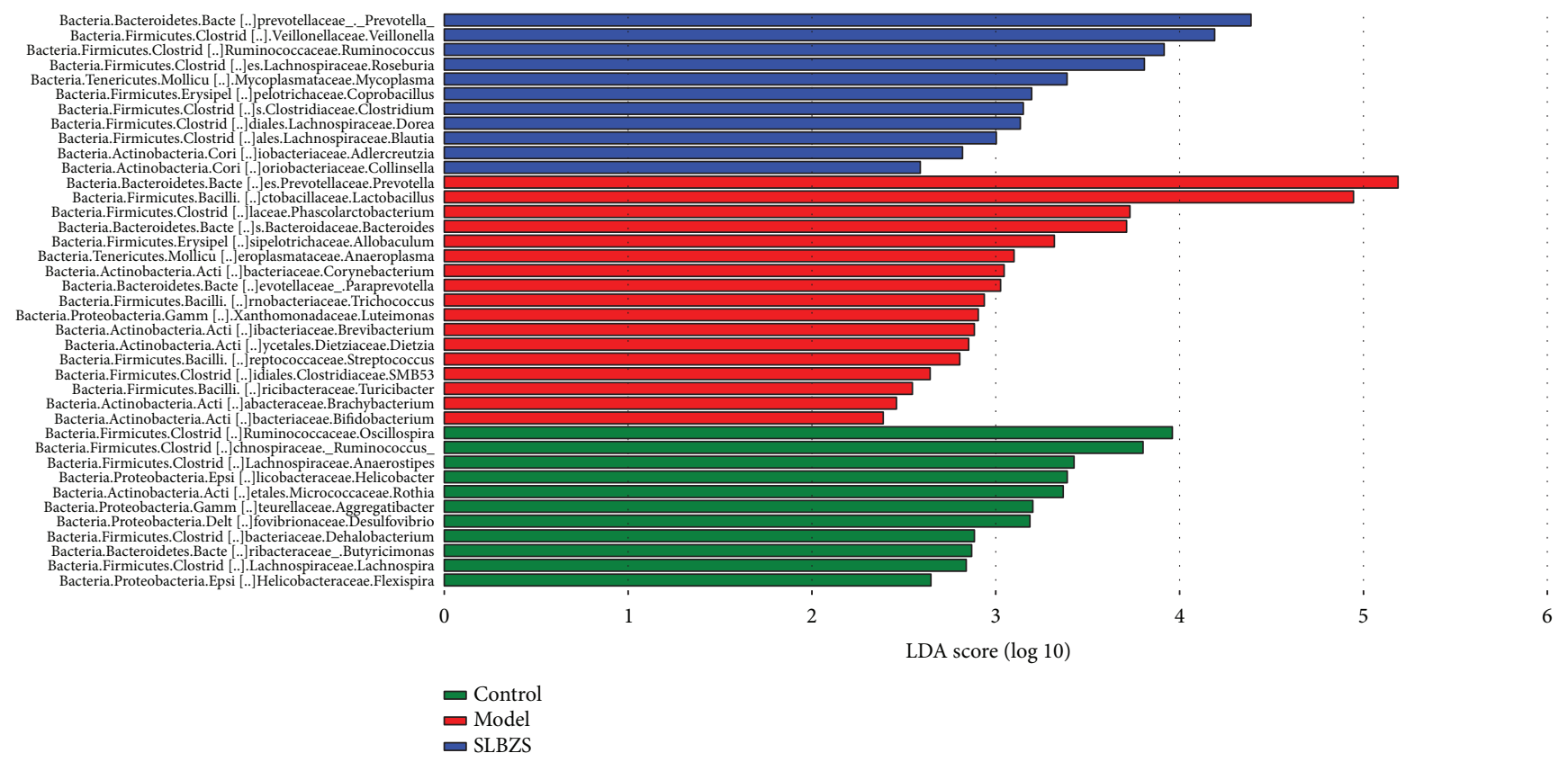

(c)

FIGURE 4: Gut microbiota analysis upon SLBZS treatment in colitic rats. (a, b) Bar plots of the taxonomic composition showing relative abundances $>1 \%$ of bacterial phyla (a) and families (b). (c) Comparison of the relative abundances of different taxa among control, model, and SLBZS-treated rats.

epithelium. This also shows that autophagy can relieve endotoxin-induced inflammatory responses in intestinal endothelial cells, thereby maintaining intestinal homeostasis [58]. Both innate and adaptive immune responses are associated with $\mathrm{NF}-\kappa \mathrm{B}$, and the development and maintenance of cells and tissues associated with the immune system are under the control of the NF- $\kappa \mathrm{B}$ transcription factor family in multiple pathways. Initially, the role of NF- $\kappa \mathrm{B}$ in the thymus was limited to the important role of RelB [59], but it became clearer in the development of medullary thymic epithelial cells [60-62].

Calcium $\left(\mathrm{Ca}^{2+}\right)$ ions are important for cell signaling, and they exert an allosteric regulation of many enzymes and proteins once they enter the cytosol of the cytoplasm. Studies have shown that intracellular $\mathrm{Ca}^{2+}$ release is accomplished by $\mathrm{Zn}^{+}$triggering inositol 1,4,5-triphosphate (IP3) $[63,64]$. Activation of mitogen-activated protein (MAP) and phosphoinositide 3 (PI3) kinase pathways protects colonic epithelial cells. In experimental colitis, metabolic calcium signaling in colonocytes is induced by zinc-induced receptors [65]. In Caco-2 cell monolayers, DSS increases the intracellular $\mathrm{Ca}^{2+}$ concentration and depletes intracellular $\mathrm{Ca}^{2+}$ by BAPTA/AM, disrupts tight junctions, and causes barrier dysfunction [66]. These findings reveal the importance of the calcium signaling pathway, which might be instrumental to the success of future human trials of a new strategy to treat digestive disease.

Chemokine receptors are cytokine receptors found on the surface of certain cells that interact with a type of cytokine called a chemokine. Chemokines can activate a range of signaling pathways to mediate their biological effects by binding to G-protein-coupled receptors (GPCRs). Duffy and D6 bind to CXC and CC inflammatory chemokines, respectively [67]. Chemokines can be divided into "inflammatory" chemokines and "steady state" chemokines [68]. Inflammatory chemokines can play important roles in recruiting leukocytes to the site of inflammation, such as neutrophils, monocyte macrophages, dendritic cells (DC), and natural killer (NK), which play key roles in the innate immune response. The results demonstrated that the chemokine signaling pathway can be further divided into modules such as survival, migration, apoptosis, cellular growth, and cytokine production. In the immune system, chemokines are mainly produced and transported by leukocytes and play an important role in the immune system [69]. Chemokines act by binding to chemokine receptors. Activation of chemokine receptors induces proliferation and differentiation of immune cells, and both are essential processes in innate and adaptive immune responses [70].

In summary, these pathways are regulated by different compounds, suggesting that digestive diseases may affect different pathways. In addition, multiple protein targets belong to a variety of signaling pathways, suggesting that certain proteins can simultaneously affect multiple signaling pathways.

In this experiment, IL- $1 \beta$, IL-10, and TNF- $\alpha$ were analyzed. IL- $1 \beta$ and TNF- $\alpha$ participate in the MAPK and NF$\kappa \mathrm{B}$ pathways, and the two pathways share crosstalk. Recent studies have shown that IL- $1 \beta$ and TNF- $\alpha$ can be proinflammatory cytokines in IBD [71-74], whereas IL-10 has been demonstrated to play a vital role in the control of inflammation and prevention of enteritis [75]. In patients with colitis and inflammatory bowel disease, damaged mitochondria 


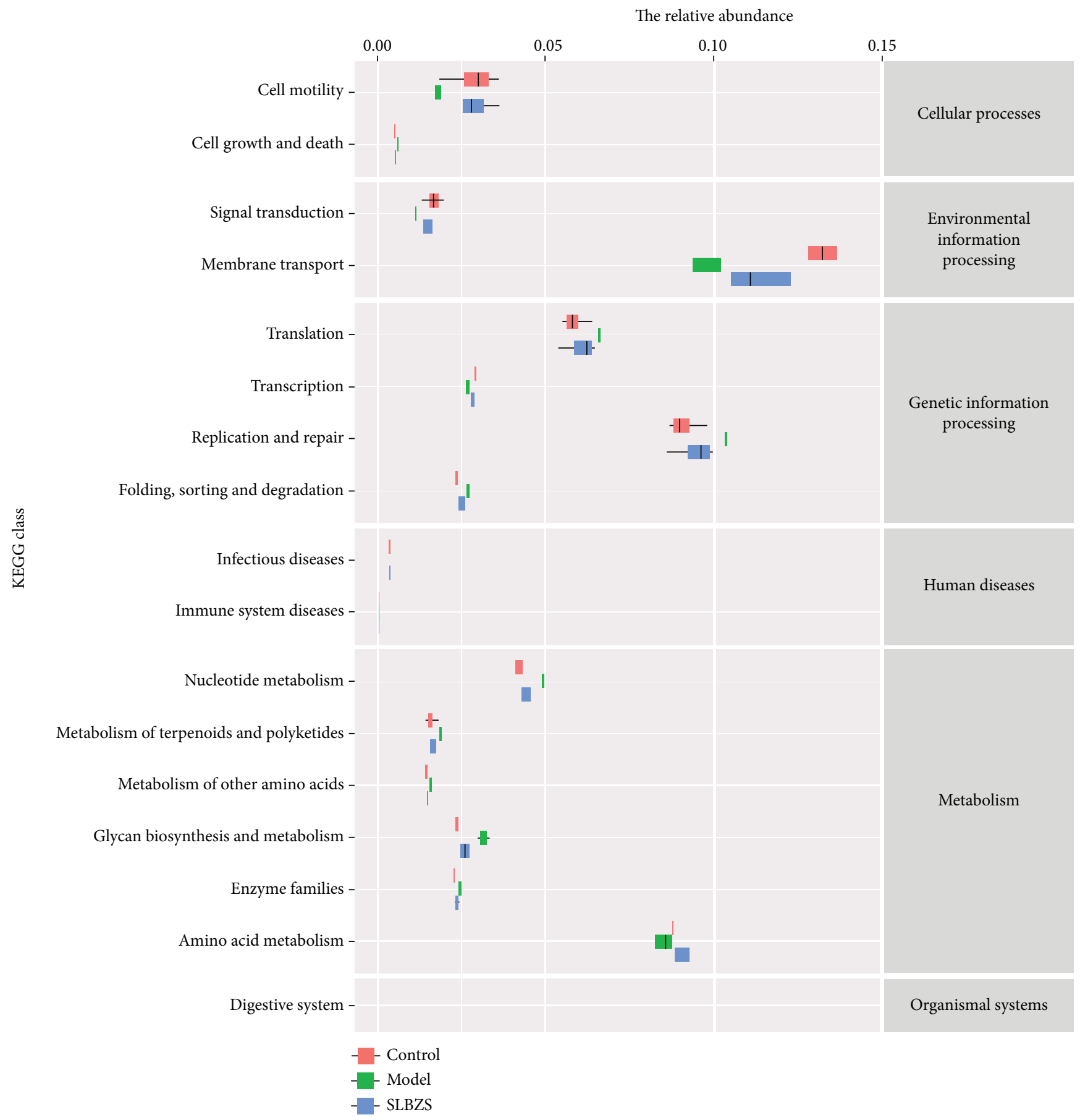

Figure 5: KEGG statistics for the functional genes. The horizontal coordinates represent the relative abundance of functional genes in different groups; the vertical coordinates represent the functions of genes. The relative abundance of functional genes in the following categories was significantly changed $(P<0.01)$.

accumulate in macrophages when IL-10 signal is deficient. This leads to abnormal activation of NLRP3 inflammasome and IL- $1 \beta$ production $[76,77]$.

In our research, changes to the intestinal microbial structure by SLBZS were observed. SLBZS treatment inhibits two genera that contain potential pathogens, Corynebacterium and Helicobacter, which are strongly associated with peptic ulcers, chronic gastritis, duodenitis, and stomach cancer [78]. Blautia is a group of bacteria containing various acetate and butyrate producers $[79,80]$. This research observed that an increase in the SCFA producer Blautia in the SLBZS treatment group was consistent with previous animal studies [81]. Roseburia and Lachnospira, as SCFA producers, were reported to recover a balanced community after diet treatment in type 2 diabetic patients [82]. Ruminococcus is present in the digestive tract of $\geq 90 \%$ of people and is involved in diseases associated with the intestines, such as IBD. A recent study demonstrated the ability of Ruminococcus to produce 


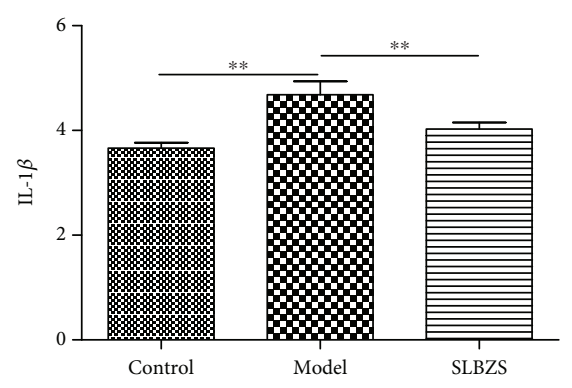

(a)

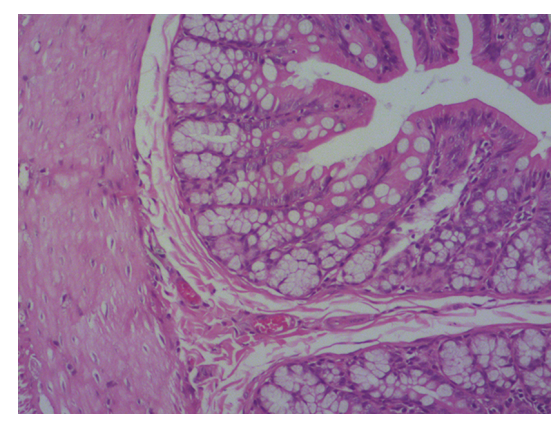

(d)

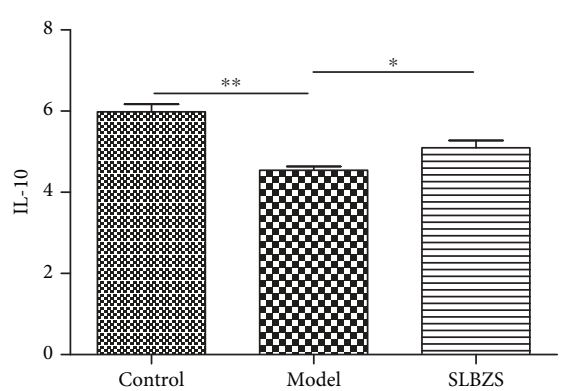

(b)

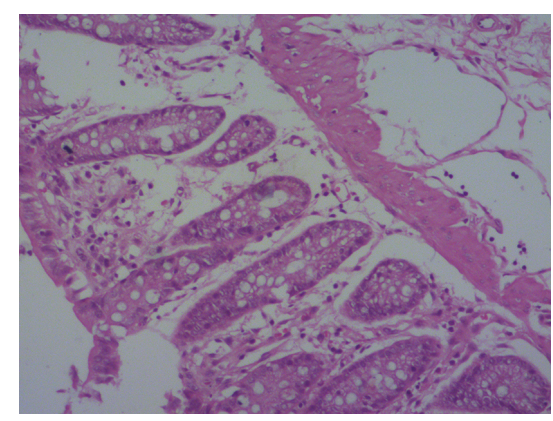

(e)

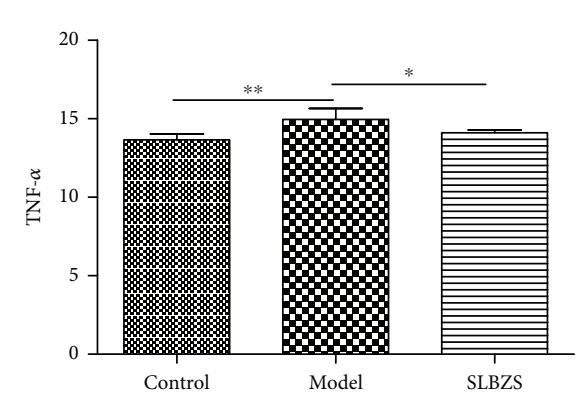

(c)

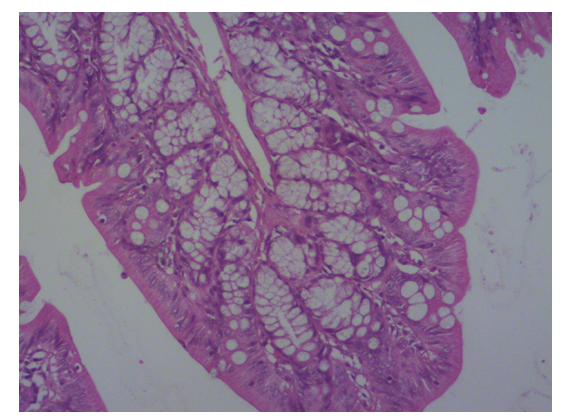

(f)

Figure 6: IL-1 $\beta$ (a), IL-10 (b), and TNF- $\alpha$ (c) can be significantly improved by SLBZS. ${ }^{*} P<0.05 ;{ }^{* *} P<0.01$. Histological changes of the colon in the control group (d), the model group (e), and the SLBZS group (f). The colon in the control group (d) presented the normal histological feature. In the model group (e), there was intestinal inflammatory cell infiltration, intestinal villus epithelial cell degeneration, necrosis, and shedding. In the SLBZS group (f), the pathological change was significantly reduced. HE staining $(\times 100)$.

propanol and propionate as the end products of metabolism [83]. These new findings provide us with insights into the specificity of the genera's adaptability to the gut environment and promote our understanding of the role of gut commensals in health and disease.

Based on the 16S rRNA results, we found that SLBZS treatment can alter the microbial structure of the intestine, which has an enhanced effect on the intestinal microbiota richness and diversity in DSS model rats. Therefore, SLBZS seems to offset the structural changes caused by DSS. As a result, the identified bacterial phylotypes in response to SLBZS treatment in DSS rats may be related to the development and improvement of DSS-induced metabolic abnormalities. The overrepresentation of the KEGG gene in the patient's microbiome can reflect the deleterious metabolism of the neurotransmitter pathway and the host gut protection glycosaminoglycan mucin, in contrast to the beneficial counterpart in the control [84]. Our PICRUSt analyses revealed that SLBZS can significantly increase amino acid metabolism, which may indicate SCFA. This is consistent with the increased SCFA-producing genera. Infectious disease, immune system disease, and digestive system disease were all reduced after treatment with SLBZS, which had a positive effect on IBD.

However, a large number of validation tests are required. The systems pharmacology results can directly prove the effect of the active compounds of SLBZS on the target, while a change in the microbiota structure can supplement the interaction between the Chinese herbal compounds and gut commensals, then revealing the underlying mechanism. Taken together, the combination of the two methods can sys- tematically illustrate the relationship among active compounds, targets, and the microbiota and contribute to the study of the mechanism of IBD.

\section{Materials and Methods}

4.1. Dataset Construction. The current data were obtained from the TCM pharmacology analysis platform (TCMSP, http://lsp.nwu.edu.cn/tcmsp.php) and a large amount of literature mining. We collected 980 compounds and their physicochemical properties from SLBZS: 14 compounds of Dolicho LablabL, 55 compounds of Atractylodes macrocephala, 34 compounds of Wolfiporia cocos, 280 compounds of Glycyrrhiza uralensis Fisch, 102 compounds of Platycodon grandiflorus, 31 compounds of Semen Nelumbinis, 190 compounds of Panax Ginseng, 165 compounds of Fructus Amomi, 71 compounds of Dioscorea opposita, and 38 compounds of Semen Coicis. Detailed information is freely available from the TCMSP analysis platform.

\subsection{Active Compound Screening Model}

4.2.1. Oral Bioavailability $(O B)$. In the present study, oral bioavailability (OB) was estimated based on OBioavail 1.1 [85] and the IntegOB. OB is one of the major pharmacokinetic parameters in the ADME (absorption, distribution, metabolism, excretion) profile of a drug. The molecule with suitable $\mathrm{OB} \geq 30 \%$ served as the candidate compound for further research.

4.2.2. Caco-2 Permeability. The oral absorption of drugs was primarily completed via intestinal epithelial cells (IEC). 
In this study, a computer Caco-2 permeability prediction model was applied to predict intestinal permeability of all TCM components in TCMSP. The number of Caco-2 molecules $>-0.4$ is considered to exhibit adequate intestinal epithelial permeability.

4.2.3. DL (Drug-Likeness). Drug-likeness is a qualitative concept used in drug design for how "druglike" a substance is with respect to factors like bioavailability. It is estimated from the molecular structure before the substance is even synthesized and tested.

4.2.4. HL (Half-Life). The half-life of a substance is the duration required for a drug to lose half of its pharmacological activity. $\mathrm{HL}=$ long is defined as a suitable half-life range.

4.3. Drug Targeting. Drug targeting was implemented by a novel computational model designed to detect the direct drug targets based on an in-house weighted ensemble similarity (WES) method [86] with satisfactory validation of both internal and external data.

4.4. Network Construction. TCM is a complex material system comprised of the effective active compound, the target of the action, and the related diseases; it does not correspond to the theory of "single gene, single target, and single disease." In order to resolve these issues, we constructed a compoundtarget network to reveal the association between the drug and the target protein. The construction of the network aided in identifying the protein targets of each compound in Chinese medicine, understanding the mechanism underlying the activity of the drug in the treatment of the disease, and studying the target in the disease network. Thus, in the generated network, nodes represent compounds, targets, signaling pathways, or diseases, while edges represent compound-target, target-disease, and target-pathway interactions. The bipartite graphs were generated using Cytoscape 2.8.1 [87].

4.5. Compound Organ Location. In order to elucidate the gut disorder at the organ level, firstly, the GO targets were analyzed for most of the selected targets, followed by the analysis of distribution in tissues and organs. Determination of target tissue distribution was based on microarray analysis data of different tissue types in BioGPS database (http://biogps.org).

$$
\begin{aligned}
\Omega & =\left\{t_{1}, t_{2}, \cdots, t_{n}\right\}, \\
H_{i} & =\left(h_{i t_{1}}, h_{i t_{2}}, \cdots, h_{i t_{n}}\right), \\
\overline{h_{i}} & =\frac{\sum_{i=1}^{n} h_{i}}{n}, \\
A_{i} & =\left\{t \in \Omega \mid t>\overline{h_{i}}\right\},
\end{aligned}
$$

wherein $t$ represents human tissue, $\Omega$ represents tissue location, $h$ represents a tissue-specific pattern of mRNA expression of one target, $H_{i}$ represents the expression position of mRNA of one target in $\Omega, \overline{h_{i}}$ represents one target in the tissue of the average expression, $n$ is the number of organizations, and $A_{i}$ indicates a target tissue location.
4.6. Animal Management. A rat model test was performed to test the effect of SLBZS on the IBD model. After a week of acclimation period, 30 rats (male and 10 weeks) were randomly divided into 3 groups-control group (CON), model group (MOD), and SLBZS group (SLBZS). The MOD and SLBZS group rats were administered 3\% DSS (40 kDa; MP Biomedicals) for 7 days, while the CON was administered with equal volume of saline. After 7 days, the SLBZS group was intragastrically administered with SLBZS $2 \mathrm{~mL}(1.2 \mathrm{~g})$ for 7 days, and the other two groups were orally given an equal volume of saline. The condition of the rats was monitored twice per day. After 24 hours of the last administration, feces, serum, and colon were collected and stored at $-80^{\circ} \mathrm{C}$. The animal experiments were approved by the Institutional Animal Care and Use Committee of South China Agricultural University (Approval No. CNAS BL0011).

4.7. Preparation of SLBZS. SLBZS was prepared using the published method [7]. SLBZS is a traditional Chinese patent medicine, composed of Panax Ginseng (10g), Wolfiporia cocos (10 g), Atractylodes macrocephala (10 g), Dioscorea opposita (10 g), Dolichos Lablab (7.5 g), Semen Nelumbinis (5 g), Semen Coicis (5 g), Fructus Amomi (5 g), Platycodon grandiflorus $(5 \mathrm{~g})$, and Glycyrrhiza uralensis Fisch $(5 \mathrm{~g})$. The ten Chinese herbs were purchased from qualified suppliers based on standards specified in the Chinese Pharmacopoeia (Guangzhou, China). The herb materials were mixed and extracted twice at $80^{\circ} \mathrm{C}$ by stirring it for $1 \mathrm{~h}$ using $10 \mathrm{vols}$ of distilled water $(\mathrm{v} / \mathrm{m})$. Then, we centrifuged the extract at $1500 \times g$ at room temperature. The SLBZS decoction was filtered and then concentrated to $1 \mathrm{~g} \mathrm{~mL}^{-1}$ (net content) with deionized water.

4.8. $16 S$ rRNA Gene Sequence Analysis of Intestinal Flora in Fecal Samples. Total genomic DNA of fecal samples was extracted by the InviMag Stool DNA Kit (Invitek, Germany) as previously described [7]. Fecal microbial DNA was extracted using Fast DNA SPIN extraction kits (MP Biomedicals, Santa Ana, CA, USA) and applied to amplification of the V3-V4 region of $16 \mathrm{~S}$ rDNA. Fecal microbiota composition was assessed using Illumina HiSeq sequencing of 16S rDNA Amplicon and QIIME-based microbial analysis. The procedures for fecal microbial DNA extraction, sequencing and library construction, and microbial analysis are described in the supplementary methods.

4.9. Histologic Observation of the Colon. Histologic colon samples were prepared as previously described [7]. The colon samples were collected and fixed in 10\% formalin, dehydrated with a sequence of ethanol solutions, embedded in paraffin, sliced ( $4-5 \mu \mathrm{m})$, and stained with hematoxylin and eosin (HE), then observed with Olympus BH22 Microscope (Japan).

4.10. Measurement of Serum Cytokines. Interleukin- (IL-) $1 \beta$, IL-10, and tumor necrosis factor-alpha (TNF- $\alpha$ ) were tested using an ELISA kit (Cusabio, Houston, TX, USA; https://www.cusabio.com/). Indices were tested according to the manufacturer's instructions. 
4.11. Quantification and Statistical Analysis. Statistical analysis was performed with GraphPad Prism 5 (GraphPad Software). Statistical significance was calculated using Kruskal-Wallis test with Dunn's multiple comparison correction. ${ }^{*} P<0.05,{ }^{* *} P<0.01$, and ${ }^{* * *} P<0.001$ were regarded as statistically significant.

$\begin{array}{ll}\text { Abbreviations } \\ \text { IBD: } & \text { Inflammatory bowel disease } \\ \text { IBS: } & \text { Irritable bowel syndrome } \\ \text { TCM: } & \text { Traditional Chinese medicine } \\ \text { IEC: } & \text { Intestinal epithelial cells } \\ \text { SLBZS: } & \text { Shen Ling Bai Zhu San } \\ \text { PICRUSt: } & \text { Phylogenetic investigation of communities by } \\ & \text { reconstruction of unobserved states } \\ \text { DSS: } & \text { Dextran sulfate sodium } \\ \text { ADME: } & \text { Absorption, distribution, metabolism, excretion } \\ \text { OB: } & \text { Oral bioavailability } \\ \text { Caco-2: } & \text { Caco-2 permeability } \\ \text { HL: } & \text { Half-life } \\ \text { DL: } & \text { Drug-likeness } \\ \text { UPGMA: } & \text { Unweighted pair-group method with arithmetic. }\end{array}$

\section{Data Availability}

The data used to support the findings of this study are available from the corresponding authors upon request.

\section{Conflicts of Interest}

All authors declare that there is no conflict of interest with any financial organization regarding the material discussed in the manuscript.

\section{Authors' Contributions}

Wei-jie Lv and Cui Liu designed the work, performed the research study, and drafted the manuscript. Zeng-quan Li, Yue-fei Li, and Wen-qian Chen participated in the experimental work. Li-min Chao, Yue Li, and Ying Xiong analyzed the database. Xiao-long $\mathrm{Xu}$ and Shi-ning Guo designed and supervised the research study. All authors read and approved the final manuscript.

\section{Acknowledgments}

We thank the Guangzhou University of Chinese Medicine Laboratory Animal Center (Guangzhou, China) for providing experimental animal and sample collecting. Thanks are due to the Shanghai Personal Biotechnology Limited Company for the analysis of data. This study was funded by the National Natural Science Foundation of China (Grant No. 31472232).

\section{Supplementary Materials}

Tissue location, alteration of phyla and genera, PICRUSt, the information of targets, the relationship between compounds and targets, topology parameters between targets and diseases, the information of pathway, topology parameters between targets and pathway, the relationship between targets and tissues, and supplementary method. (Supplementary Materials)

\section{References}

[1] S. Danese and C. Fiocchi, "Ulcerative colitis," The New England Journal of Medicine, vol. 365, no. 18, pp. 1713-1725, 2011.

[2] B. Khor, A. Gardet, and R. J. Xavier, "Genetics and pathogenesis of inflammatory bowel disease," Nature, vol. 474, no. 7351, pp. 307-317, 2011.

[3] D. P. McGovern, S. Kugathasan, and J. H. Cho, "Genetics of inflammatory bowel diseases," Gastroenterology, vol. 149, no. 5, pp. 1163-1176.e2, 2015.

[4] N. A. Molodecky, I. S. Soon, D. M. Rabi et al., "Increasing incidence and prevalence of the inflammatory bowel diseases with time, based on systematic review," Gastroenterology, vol. 142, no. 1, pp. 46-54.e42, 2012, e42; quiz e30.

[5] J. M. Peloquin, G. Goel, E. J. Villablanca, and R. J. Xavier, "Mechanisms of pediatric inflammatory bowel disease," Annual Review of Immunology, vol. 34, no. 1, pp. 31-64, 2016.

[6] C. Liu, C. Zhang, W. J. Lv et al., "Structural modulation of gut microbiota during alleviation of suckling piglets diarrhoea with herbal formula," Evidence-based Complementary and Alternative Medicine, vol. 2017, Article ID 8358151, 11 pages, 2017.

[7] W. J. Lv, C. Liu, C. X. Ye et al., "Structural modulation of gut microbiota during alleviation of antibiotic-associated diarrhea with herbal formula," International Journal of Biological Macromolecules, vol. 105, Part 3, pp. 1622-1629, 2017.

[8] D. Normile, "Asian medicine: the new face of traditional Chinese medicine," Science, vol. 299, no. 5604, pp. 188-190, 2003.

[9] D. C. Hao and P. G. Xiao, "Network pharmacology: a Rosetta Stone for traditional Chinese medicine," Drug Development Research, vol. 75, no. 5, pp. 299-312, 2014.

[10] A. L. Hopkins, "Network pharmacology: the next paradigm in drug discovery," Nature Chemical Biology, vol. 4, no. 11, pp. 682-690, 2008

[11] S. C. Janga and A. Tzakos, "Structure and organization of drugtarget networks: insights from genomic approaches for drug discovery," Molecular BioSystems, vol. 5, no. 12, pp. 1536-1548, 2009.

[12] I. Sekirov, S. L. Russell, L. C. Antunes, and B. B. Finlay, "Gut microbiota in health and disease," Physiological Reviews, vol. 90, no. 3, pp. 859-904, 2010.

[13] A. C. Ford, B. M. R. Spiegel, N. J. Talley, and P. Moayyedi, "Small intestinal bacterial overgrowth in irritable bowel syndrome: systematic review and meta-analysis," Clinical Gastroenterology and Hepatology, vol. 7, no. 12, pp. 1279-1286, 2009.

[14] A. Salonen, W. M. de Vos, and A. Palva, "Gastrointestinal microbiota in irritable bowel syndrome: present state and perspectives," Microbiology, vol. 156, no. 11, pp. 3205-3215, 2010.

[15] C. Huang, C. L. Zheng, Y. Li, Y. H. Wang, A. P. Lu, and L. Yang, "Systems pharmacology in drug discovery and therapeutic insight for herbal medicines," Briefings in Bioinformatics, vol. 15, no. 5, pp. 710-733, 2014.

[16] S. W. Zhao and S. Li, "Network-based relating pharmacological and genomic spaces for drug target identification," PLoS One, vol. 5, no. 7, article e11764, 2010. 
[17] J. R. White, N. Nagarajan, and M. Pop, "Statistical methods for detecting differentially abundant features in clinical metagenomic samples," PLoS Computational Biology, vol. 5, no. 4, article e1000352, 2009.

[18] P. M. Munyaka, M. F. Rabbi, E. Khafipour, and J. E. Ghia, "Acute dextran sulfate sodium (DSS)-induced colitis promotes gut microbial dysbiosis in mice," Journal of Basic Microbiology, vol. 56, no. 9, pp. 986-998, 2016.

[19] T. Osaka, E. Moriyama, S. Arai et al., "Meta-analysis of fecal microbiota and metabolites in experimental colitic mice during the inflammatory and healing phases," Nutrients, vol. 9, no. 12, p. 1329, 2017.

[20] D. Gevers, S. Kugathasan, L. A. Denson et al., "The treatmentnaive microbiome in new-onset Crohn's disease," Cell Host \& Microbe, vol. 15, no. 3, pp. 382-392, 2014.

[21] A. Koh, F. De Vadder, P. Kovatcheva-Datchary, and F. Backhed, "From dietary fiber to host physiology: shortchain fatty acids as key bacterial metabolites," Cell, vol. 165, no. 6, pp. 1332-1345, 2016.

[22] N. W. Palm, M. R. de Zoete, T. W. Cullen et al., "Immunoglobulin A coating identifies colitogenic bacteria in inflammatory bowel disease," Cell, vol. 158, no. 5, pp. 10001010, 2014.

[23] M. G. I. Langille, J. Zaneveld, J. G. Caporaso et al., "Predictive functional profiling of microbial communities using $16 \mathrm{~S}$ rRNA marker gene sequences," Nature Biotechnology, vol. 31, no. 9, pp. 814-821, 2013.

[24] P. A. Ayeka, Y. H. Bian, P. M. Githaiga, and Y. Zhao, "The immunomodulatory activities of licorice polysaccharides (Glycyrrhiza uralensis Fisch.) in CT 26 tumor-bearing mice," BMC Complementary and Alternative Medicine, vol. 17, no. 1, p. 536, 2017.

[25] Y. S. Baraya, K. K. Wong, and N. S. Yaacob, "The immunomodulatory potential of selected bioactive plant-based compounds in breast cancer: a review," Anti-Cancer Agents in Medicinal Chemistry, vol. 17, no. 6, pp. 770-783, 2017.

[26] H. Kang, Y. G. Hwang, T. G. Lee et al., "Use of gold nanoparticle fertilizer enhances the ginsenoside contents and antiinflammatory effects of red ginseng," Journal of Microbiology and Biotechnology, vol. 26, no. 10, pp. 1668-1674, 2016.

[27] Y. Shimato, M. Ota, K. Asai, T. Atsumi, Y. Tabuchi, and T. Makino, "Comparison of byakujutsu (Atractylodes rhizome) and sojutsu (Atractylodes lancea rhizome) on antiinflammatory and immunostimulative effects in vitro," Journal of Natural Medicines, vol. 72, no. 1, pp. 192-201, 2018.

[28] Y. O. Son, S. H. Kook, and J. C. Lee, "Glycoproteins and polysaccharides are the main class of active constituents required for lymphocyte stimulation and antigen-specific immune response induction by traditional medicinal herbal plants," Journal of Medicinal Food, vol. 20, no. 10, pp. 1011-1021, 2017.

[29] R. Yang, B. C. Yuan, Y. S. Ma, S. Zhou, and Y. Liu, “The anti-inflammatory activity of licorice, a widely used Chinese herb," Pharmaceutical Biology, vol. 55, no. 1, pp. 5-18, 2017.

[30] S. Kang and H. Min, "Ginseng, the 'immunity boost': the effects of Panax ginseng on immune system," Journal of Ginseng Research, vol. 36, no. 4, pp. 354-368, 2012.

[31] C. Chen, J. Zhou, and C. Y. Ji, "Quercetin: a potential drug to reverse multidrug resistance," Life Sciences, vol. 87, no. 11-12, pp. 333-338, 2010.
[32] Y. Lin, R. X. Shi, X. Wang, and H. M. Shen, "Luteolin, a flavonoid with potential for cancer prevention and therapy," Current Cancer Drug Targets, vol. 8, no. 7, pp. 634-646, 2008.

[33] M. Aprile, M. R. Ambrosio, V. D'Esposito et al., " $P P A R G$ in human adipogenesis: differential contribution of canonical transcripts and dominant negative isoforms," Ppar Research, vol. 2014, Article ID 537865, 11 pages, 2014.

[34] Y. Kang, S. Hengbo, L. Jun et al., "PPARG modulated lipid accumulation in dairy GMEC via regulation of ADRP gene," Journal of Cellular Biochemistry, vol. 116, no. 1, pp. 192-201, 2015.

[35] G. Y. Xu, H. S. Shi, L. B. Ren, G. Xu, H. Gou, and D. Gong, "Enhancing the anti-colon cancer activity of quercetin by self-assembled micelles," International Journal of Nanomedicine, vol. 10, pp. 2051-2063, 2015.

[36] L. Delgado, I. Fernandes, S. Gonzalez-Manzano, V. de Freitas, N. Mateus, and C. Santos-Buelga, "Anti-proliferative effects of quercetin and catechin metabolites," Food \& Function, vol. 5, no. 4, pp. 797-803, 2014.

[37] S. F. Nabavi, N. Braidy, O. Gortzi et al., "Luteolin as an antiinflammatory and neuroprotective agent: a brief review," Brain Research Bulletin, vol. 119, Part A, pp. 1-11, 2015.

[38] J. Lu, G. L. Li, K. F. He et al., "Luteolin exerts a marked antitumor effect in cMet-overexpressing patient-derived tumor xenograft models of gastric cancer," Journal of Translational Medicine, vol. 13, no. 1, p. 42, 2015.

[39] L. Zemanova, J. Hofman, E. Novotna et al., "Flavones inhibit the activity of AKR1B10, a promising therapeutic target for cancer treatment," Journal of Natural Products, vol. 78, no. 11, pp. 2666-2674, 2015.

[40] X. P. Ci, C. S. Xing, B. T. Zhang et al., "KLF5 inhibits angiogenesis in PTEN-deficient prostate cancer by attenuating AKT activation and subsequent HIF1 $\alpha$ accumulation," Cancer Research, vol. 14, no. 1, p. 91, 2015.

[41] W. F. Tang, Y. M. Chen, Y. F. Wang, H. Y. Gu, S. C. Chen, and M. Q. Kang, "Peroxisome proliferator-activated receptor gamma (PPARG) polymorphisms and breast cancer susceptibility: a meta-analysis," International Journal of Clinical and Experimental Medicine, vol. 8, no. 8, pp. 12226-12238, 2015.

[42] Z. J. Zhang, Z. Y. Yan, Z. Yuan, Y. Z. Sun, H. F. He, and C. Y. Mai, "RETRACTED ARTICLE: SPHK1 inhibitor suppresses cell proliferation and invasion associated with the inhibition of NF- $\kappa$ B pathway in hepatocellular carcinoma," Tumor Biology, vol. 36, no. 3, pp. 1503-1509, 2015.

[43] E. Canbay, O. Kurnaz, B. Canbay et al., "PPAR-gamma Pro12Ala polymorphism and gastric cancer risk in a Turkish population," Asian Pacific Journal of Cancer Prevention, vol. 13, no. 11, pp. 5875-5878, 2012.

[44] P. Biancheri, R. J. Brezski, A. Di Sabatino et al., "Proteolytic cleavage and loss of function of biologic agents that neutralize tumor necrosis factor in the mucosa of patients with inflammatory bowel disease," Gastroenterology, vol. 149, no. 6, pp. 1564-1574.e3, 2015.

[45] D. Gingras, A. Renaud, N. Mousseau, E. Beaulieu, Z. Kachra, and R. Beliveau, "Matrix proteinase inhibition by AE-941, a multifunctional antiangiogenic compound," Anticancer Research, vol. 21, no. 1A, pp. 145-155, 2001.

[46] G. P. Vandoros, P. A. Konstantinopoulos, G. SotiropoulouBonikou et al., "PPAR-gamma is expressed and NF-KB pathway is activated and correlates positively with COX-2 expression in stromal myofibroblasts surrounding colon adenocarcinomas," 
Journal of Cancer Research and Clinical Oncology, vol. 132, no. 2, pp. 76-84, 2006.

[47] W. S. Cho and C. Chae, "Expression of cyclooxygenase-2 and nitric oxide synthase 2 in swine ulcerative colitis caused by Salmonella typhimurium," Veterinary Pathology, vol. 41, no. 4, pp. 419-423, 2004.

[48] Y. Naito, K. Uchiyama, T. Takagi, and T. Yoshikawa, "Therapeutic potential of carbon monoxide (CO) for intestinal inflammation," Current Medicinal Chemistry, vol. 19, no. 1, pp. 70-76, 2012.

[49] Q. H. Yang, Y. J. Xu, Y. Z. Liu et al., "Effects of ChaihuShugan-San and Shen-Ling-Bai-Zhu-San on p38 MAPK pathway in Kupffer cells of nonalcoholic steatohepatitis," Evidencebased Complementary and Alternative Medicine, vol. 2014, Article ID 671013, 8 pages, 2014.

[50] R. A. Bozym, K. Patel, C. White et al., "Calcium signals and calpain-dependent necrosis are essential for release of coxsackievirus B from polarized intestinal epithelial cells," Molecular Biology of the Cell, vol. 22, no. 17, pp. 3010-3021, 2011.

[51] S. Mukherjee, D. Sinha, A. K. Ghosh, and T. Biswas, "Bacterial ligand stimulates TLR2-dependent chemokines of colon cell," Immunobiology, vol. 219, no. 5, pp. 350-356, 2014.

[52] T. Wang, X. Song, Z. Zhang et al., "Stevioside inhibits inflammation and apoptosis by regulating TLR2 and TLR2-related proteins in S. aureus-infected mouse mammary epithelial cells," International Immunopharmacology, vol. 22, no. 1, pp. 192-199, 2014.

[53] W. H. Hsu, Y. S. Hsieh, H. C. Kuo et al., "Berberine induces apoptosis in SW620 human colonic carcinoma cells through generation of reactive oxygen species and activation of JNK/p38 MAPK and FasL," Archives of Toxicology, vol. 81, no. 10, pp. 719-728, 2007.

[54] X. B. Ling, H. W. Wei, J. Wang et al., "Mammalian metallothionein-2A and oxidative stress," International Journal of Molecular Sciences, vol. 17, no. 9, p. 1483, 2016.

[55] N. Shi, F. Chen, X. L. Zhang et al., "Suppression of oxidative stress and NF $\kappa$ B/MAPK signaling by lyophilized black raspberries for esophageal cancer prevention in rats," Nutrients, vol. 9, no. 4, p. 413, 2017.

[56] H. L. Song, X. Zhang, W. Z. Wang et al., "Neuroprotective mechanisms of rutin for spinal cord injury through antioxidation and anti-inflammation and inhibition of p38 mitogen activated protein kinase pathway," Neural Regeneration Research, vol. 13, no. 1, pp. 128-134, 2018.

[57] M. S. Hayden and S. Ghosh, "NF- $\kappa$ B, the first quarter-century: remarkable progress and outstanding questions," Genes \& Development, vol. 26, no. 3, pp. 203-234, 2012.

[58] Y. Fujishima, S. Nishiumi, A. Masuda et al., "Autophagy in the intestinal epithelium reduces endotoxin-induced inflammatory responses by inhibiting NF- $\kappa \mathrm{B}$ activation," Archives of Biochemistry and Biophysics, vol. 506, no. 2, pp. 223235, 2011.

[59] L. Burkly, C. Hession, L. Ogata et al., "Expression of relB is required for the development of thymic medulla and dendritic cells," Nature, vol. 373, no. 6514, pp. 531-536, 1995.

[60] M. Irla, S. Hugues, J. Gill et al., "Autoantigen-specific interactions with $\mathrm{CD} 4(+)$ thymocytes control mature medullary thymic epithelial cell cellularity," Immunity, vol. 29, no. 3, pp. 451-463, 2008.

[61] Y. Hikosaka, T. Nitta, I. Ohigashi et al., "The cytokine RANKL produced by positively selected thymocytes fosters medullary thymic epithelial cells that express autoimmune regulator," Immunity, vol. 29, no. 3, pp. 438-450, 2008.

[62] T. Akiyama, Y. Shimo, H. Yanai et al., "The tumor necrosis factor family receptors RANK and CD40 cooperatively establish the thymic medullary microenvironment and self-tolerance," Immunity, vol. 29, no. 3, pp. 423-437, 2008.

[63] N. Dubi, L. Gheber, D. Fishman, I. Sekler, and M. Hershfinkel, "Extracellular zinc and zinc-citrate, acting through a putative zinc-sensing receptor, regulate growth and survival of prostate cancer cells," Carcinogenesis, vol. 29, no. 9, pp. 1692-1700, 2008.

[64] H. Azriel-Tamir, H. Sharir, B. Schwartz, and M. Hershfinkel, "Extracellular zinc triggers ERK-dependent activation of $\mathrm{Na}$ $+/ \mathrm{H}+$ exchange in colonocytes mediated by the zinc-sensing receptor," The Journal of Biological Chemistry, vol. 279, no. 50, pp. 51804-51816, 2004.

[65] L. Sunuwar, M. Medini, L. Cohen, I. Sekler, and M. Hershfinkel, "The zinc sensing receptor, ZnR/GPR39, triggers metabotropic calcium signalling in colonocytes and regulates occludin recovery in experimental colitis," Philosophical Transactions of the Royal Society B-Biological Sciences, vol. 371, no. 1703, article 20160331, 2016.

[66] G. Samak, K. K. Chaudhry, R. Gangwar, D. Narayanan, J. H. Jaggar, and R. K. Rao, "Calcium/Ask1/MKK7/JNK2/c-Src signalling cascade mediates disruption of intestinal epithelial tight junctions by dextran sulfate sodium," Biochemical Journal, vol. 465, no. 3, pp. 503-515, 2015.

[67] L. Gardner, A. M. Patterson, B. A. Ashton, M. A. Stone, and J. Middleton, "The human Duffy antigen binds selected inflammatory but not homeostatic chemokines," Biochemical and Biophysical Research Communications, vol. 321, no. 2, pp. 306-312, 2004.

[68] N. W. Lukacs, "Role of chemokines in the pathogenesis of asthma," Nature Reviews. Immunology, vol. 1, no. 2, pp. 108116, 2001.

[69] A. Zlotnik and O. Yoshie, "The chemokine superfamily revisited," Immunity, vol. 36, no. 5, pp. 705-716, 2012.

[70] C. Esche, C. Stellato, and L. A. Beck, "Chemokines: key players in innate and adaptive immunity," Journal of Investigative Dermatology, vol. 125, no. 4, pp. 615-628, 2005.

[71] M. Grizotte-Lake and S. Vaishnava, "Autophagy: suicide prevention hotline for the gut epithelium," Cell Host \& Microbe, vol. 23, no. 2, pp. 147-148, 2018.

[72] Q. Hou, L. Ye, H. Liu et al., "Lactobacillus accelerates ISCs regeneration to protect the integrity of intestinal mucosa through activation of STAT3 signaling pathway induced by LPLs secretion of IL-22," Cell Death and Differentiation, vol. 25, no. 9, pp. 1657-1670, 2018.

[73] R. Dey, A. B. Joshi, F. Oliveira et al., "Gut microbes egested during bites of infected sand flies augment severity of leishmaniasis via inflammasome-derived IL-1 $\beta$," Cell Host \& Microbe, vol. 23, no. 1, pp. 134-143.e6, 2018.

[74] V. Neudecker, M. Haneklaus, O. Jensen et al., "Myeloidderived miR-223 regulates intestinal inflammation via repression of the NLRP3 inflammasome," Journal of Experimental Medicine, vol. 214, no. 6, pp. 1737-1752, 2017.

[75] C. Burrello, F. Garavaglia, F. M. Cribiù et al., "Therapeutic faecal microbiota transplantation controls intestinal inflammation through IL10 secretion by immune cells," Nature Communications, vol. 9, no. 1, article 5184, 2018. 
[76] W. K. E. Ip, N. Hoshi, D. S. Shouval, S. Snapper, and R. Medzhitov, "Anti-inflammatory effect of IL-10 mediated by metabolic reprogramming of macrophages," Science, vol. 356, no. 6337, pp. 513-519, 2017.

[77] A. M. Kabat and E. J. Pearce, "Inflammation by way of macrophage metabolism," Science, vol. 356, no. 6337, pp. 488-489, 2017.

[78] Q. Yu, S. Zhang, L. Li et al., "P716. Enterohepatic helicobacter species as a potentially causative factor of inflammatory bowel disease: a meta-analysis," Journal of Crohn's and Colitis, vol. 9, Supplement 1, pp. S439-S440, 2015.

[79] S. K. Park, M. S. Kim, and J. W. Bae, "Blautia faecis sp. nov., isolated from human faeces," International Journal of Systematic and Evolutionary Microbiology, vol. 63, pp. 599-603, 2012.

[80] S. K. Park, M. S. Kim, S. W. Roh, and J. W. Bae, "Blautia stercoris sp. nov., isolated from human faeces," International Journal of Systematic and Evolutionary Microbiology, vol. 62, Part 4, pp. 776-779, 2012.

[81] X. Zhang, Y. Zhao, J. Xu et al., "Modulation of gut microbiota by berberine and metformin during the treatment of high-fat diet-induced obesity in rats," Scientific Reports, vol. 5, no. 1, article 14405, 2015.

[82] M. Candela, E. Biagi, M. Soverini et al., "Modulation of gut microbiota dysbioses in type 2 diabetic patients by macrobiotic Ma-Pi 2 diet," The British Journal of Nutrition, vol. 116, no. 1, pp. 80-93, 2016.

[83] E. H. Crost, L. E. Tailford, G. Le Gall, M. Fons, B. Henrissat, and N. Juge, "Utilisation of mucin glycans by the human gut symbiont Ruminococcus gnavus is strain-dependent," PLoS One, vol. 8, no. 10, article e76341, 2013.

[84] B. R. Stevens, R. Goel, K. Seungbum et al., "Increased human intestinal barrier permeability plasma biomarkers zonulin and FABP2 correlated with plasma LPS and altered gut microbiome in anxiety or depression," Gut, vol. 67, no. 8, 2018.

[85] X. Xu, W. X. Zhang, C. Huang et al., "A novel chemometric method for the prediction of human oral bioavailability," International Journal of Molecular Sciences, vol. 13, no. 6, pp. 6964-6982, 2012.

[86] C. L. Zheng, Z. H. Guo, C. Huang et al., "Large-scale direct targeting for drug repositioning and discovery," Scientific Reports, vol. 5, no. 1, article 11970, 2015.

[87] M. E. Smoot, K. Ono, J. Ruscheinski, P. L. Wang, and T. Ideker, "Cytoscape 2.8: new features for data integration and network visualization," Bioinformatics, vol. 27, no. 3, pp. 431-432, 2011. 


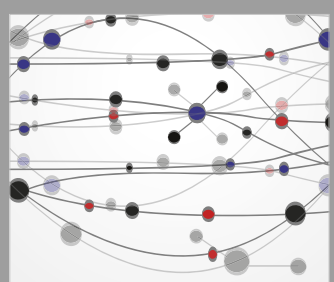

The Scientific World Journal
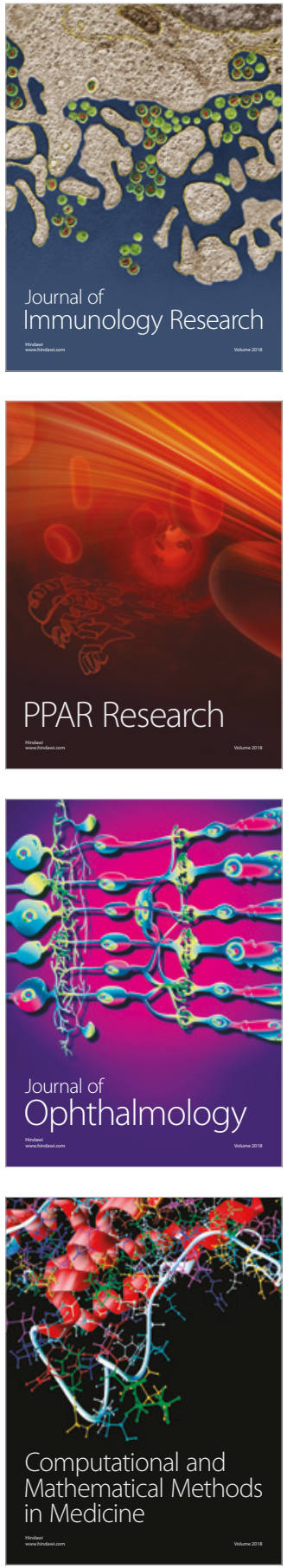

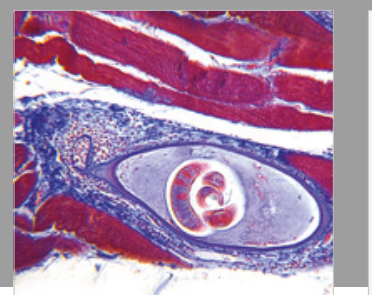

Gastroenterology Research and Practice

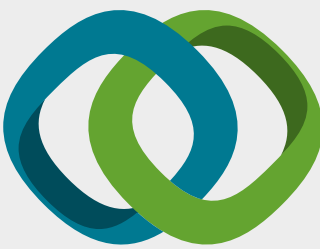

\section{Hindawi}

Submit your manuscripts at

www.hindawi.com
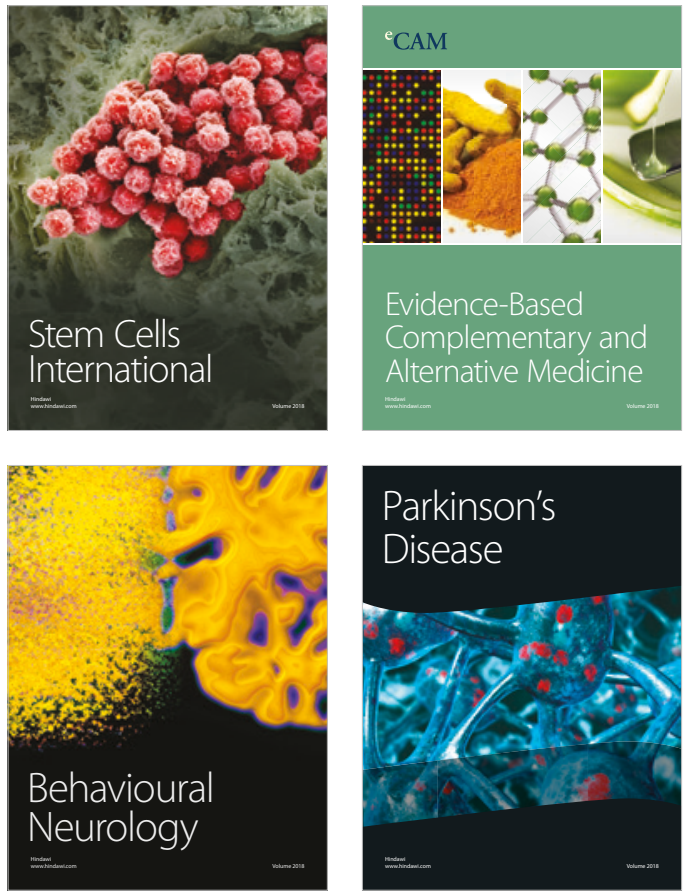

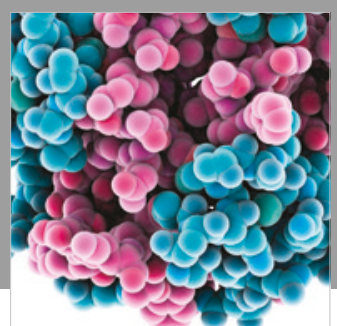

ournal of

Diabetes Research

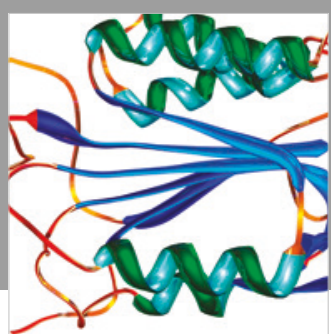

Disease Markers
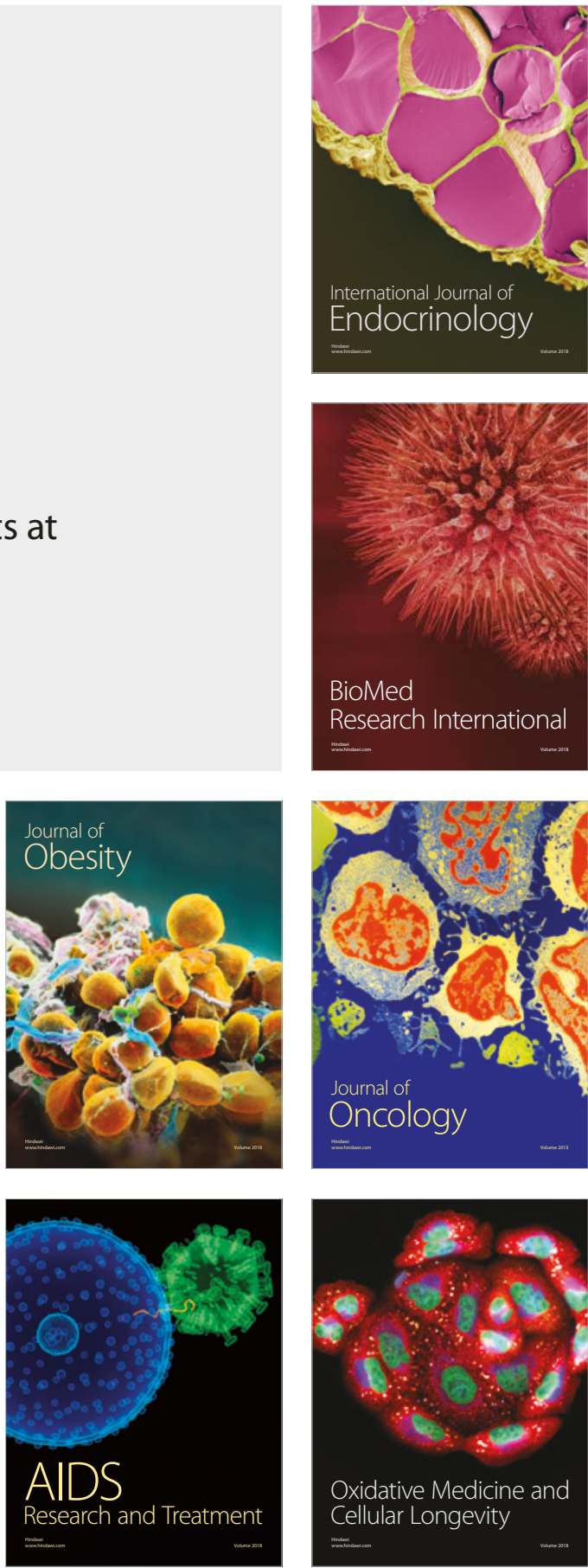